\title{
Prochlorococcus marinus Chisholm et al. 1992 subsp. pastoris subsp. nov. strain PCC 9511, the first axenic chlorophyll $a_{2} / b_{2}$-containing cyanobacterium (Oxyphotobacteria)
}

\author{
Rosmarie Rippka, ${ }^{1}$ Thérèse Coursin, ${ }^{1}$ Wolfgang Hess, ${ }^{2}$ Christiane Lichtlé, ${ }^{3}$ \\ David J. Scanlan, ${ }^{4}$ Katarzyna A. Palinska, ${ }^{1}$ Isabelle Iteman, ${ }^{1}$ \\ Frédéric Partensky, ${ }^{5}$ Jean Houmard ${ }^{1} \dagger$ and Michael Herdman ${ }^{1}$
}

1 Unité de Physiologie Microbienne (CNRS URA 1129), Département de Biochimie et Génétique Moléculaire, Institut Pasteur, 28 Rue du Dr Roux, 75724 Paris Cedex 15, France

2 Department of Biology, Humboldt-University, Chausseestrasse 117, D-10115 Berlin, Germany

${ }^{3}$ Laboratoire de Photorégulation et Dynamique des Membranes Végétales, Ecole Normale Supérieure (CNRS URA 1810), 46 Rue d'Ulm, 75230 Paris Cedex 05, France

4 Department of Biological Sciences, University of Warwick, Gibbet Hill Road, Coventry CV4 7AL, UK

5 Station Biologique de Roscoff (CNRS UPR 9042) et Université Paris VI, BP 74, 29682 Roscoff Cedex, France

\begin{abstract}
Author for correspondence: Rosmarie Rippka. Tel: +3314568 84 16. Fax: +33140613042. e-mail: rrippka@pasteur.fr
\end{abstract}

\begin{abstract}
The formal description of Prochlorococcus marinus Chisholm et al. 1992, 299 was based on the non-axenic nomenclatural type, strain CCMP 1375'. The purification and properties of the axenic strain PCC 9511, derived from the same primary culture (SARG) as the type species, are reported here. Prochlorococcus PCC 9511 differs from the latter in possessing horseshoeshaped thylakoids, exhibiting a low chlorophyll $b_{2}$ content and lacking phycoerythrin, but shares these phenotypic properties with Prochlorococcus strain CCMP 1378. This relationship was confirmed by 165 rRNA sequence analyses, which clearly demonstrated that the axenic isolate is not co-identic with the nomenclatural type. Strain PCC 9511 has a low mean DNA base composition ( $32 \mathrm{~mol} \% \mathrm{G}+\mathrm{C}$ ) and harbours the smallest genome of all known oxyphotobacteria (genome complexity 1.3 GDa $=2 \mathrm{Mbp}$ ). Urea and ammonia are the preferred sources of nitrogen for growth, whereas nitrate is not utilized. Several different organic phosphorus compounds efficiently replace phosphate in the culture medium, indicative of ecto-phosphohydrolase activity. In order to distinguish strain PCC 9511 from the nomenclatural type, a new subspecies is proposed, Prochlorococcus marinus Chisholm et al. 1992 subsp. pastoris subsp. nov.
\end{abstract}

Keywords: Prochlorales, cyanobacteria, nitrogen assimilation, phosphohydrolases, $16 \mathrm{~S}$ rRNA

\begin{abstract}
This paper is dedicated in gratitude to Professor Germaine Cohen-Bazire on the occasion of her 80th birthday. Together with her late husband, Professor R. Y. Stanier, Germaine gave the members of the Physiologie Microbienne (Institute Pasteur, Paris) generous scientific guidance and spiritual support over many years (1971-1988).

†Present address: Laboratoire de Photorégulation et Dynamique des Membranes Végétales, Ecole Normale Supérieure (CNRS URA 1810), 46 Rue d'Ulm, 75230 Paris Cedex 05, France.

Abbreviations: chl, chlorophyll; HL, high light; LL, low light; PPFD, photosynthetic photon flux density; $\mathrm{PE}$, phycoerythrin; $T_{\mathrm{m}}$, temperature mid-point of denaturation.

The GenBank accession numbers for the 16S rRNA sequences of PCC 9511, CCMP 1426 and NATL1 are AF180967, AF133833 and AF133834, respectively.
\end{abstract}

\section{INTRODUCTION}

In the last edition of Bergey's Manual of Systematic Bacteriology, the class Oxyphotobacteria was subdivided into the Cyanobacteria, whose ordinal recognition still awaits validation, and the order Prochlorales Lewin 1977 (Castenholz \& Waterbury, 1989). In the light, like algae and plants, these photosynthetic prokaryotes use $\mathrm{H}_{2} \mathrm{O}$ for the generation of chemical energy and reducing power and liberate molecular $\mathrm{O}_{2}$ as a by-product. The demand for cellular carbon is met by $\mathrm{CO}_{2}$ fixation. Cyanobacteria synthesize monovinyl chlorophyll $a$ (chl $\left.a_{1}\right)$ and harvest light by aid of watersoluble multimeric complexes, the phycobilisomes, composed of biliproteins and linker polypeptides 
(Glazer, 1987, 1989; Sidler, 1994). In contrast, oxyphotobacteria of the order Prochlorales Lewin 1977 either lack phycobiliproteins entirely, or synthesize only trace amounts (Lewin, 1977, 1989; BurgerWiersma et al., 1986; Chisholm et al., 1992; Hess et al., 1996). Their light-harvesting complexes are membrane-associated proteins containing chlorophyll $a\left(a_{1}\right.$ or $\left.a_{2}\right)$ and chlorophyll $b\left(b_{1}\right.$ or $\left.b_{2}\right)$ as the major photosynthetic pigments (Burger-Wiersma et al., 1986; Goericke \& Repeta, 1992; Partensky et al., 1997). In spite of these unifying traits, the representatives of the Prochlorales, Prochloron didemni Lewin 1977, Prochlorothrix hollandica Burger-Wiersma et al. 1986 and Prochlorococcus marinus Chisholm et al. 1992, do not form a monophyletic lineage but evolved in multiple and independent events within the cyanobacterial radiation (Turner et al., 1989; Kishino et al., 1990; Lockhart et al., 1992; Palenik \& Haselkorn, 1992; Urbach et al., 1992; Hess et al., 1995). Consequently, the order Prochlorales is no longer justified, its members merely being atypical representatives of the Cyanobacteria (Palenik \& Haselkorn, 1992; Urbach et al., 1992, 1998; Pinevich et al., 1997).

The genus Prochlorococcus was created for two nonaxenic isolates, both of which were assigned to a single species, P. marinus Chisholm et al. 1992, 299 (Chisholm et al., 1992). The holotype, strain CCMP $1375^{\mathrm{T}}$, originated from a depth of $120 \mathrm{~m}$ in the Sargasso Sea, near the bottom of the euphotic zone, whereas strain CCMP 1378 was isolated from surface water $(5 \mathrm{~m})$ of the northwestern Mediterranean Sea (Chisholm et al., 1992; Partensky et al., 1993). The former strain is also known as SS120, whereas the latter has been cited as MED4 (Moore et al., 1995; Partensky et al., 1999). Both isolates have very small, coccoid to rod-shaped cells (diameter $0.6-0.8 \mu \mathrm{m}$ ) that exhibit red fluorescence when excited by blue light (488 nm) (Chisholm et al., 1992; Goericke \& Repeta, 1992). Representatives of this novel group of oxygenic phototrophs, first characterized by aid of flow cytometry, pigment analysis and electron microscopy (Chisholm et al., 1988, 1992; Li \& Wood, 1988), are ubiquitous and abundant $\left(10^{4}-5 \times 10^{5}\right.$ cells $\left.\mathrm{ml}^{-1}\right)$ in the water column $(0-200 \mathrm{~m})$ of most tropical and temperate oceans (for a review, see Partensky et al., 1999). They generally dominate the bottom of the euphotic zone (100-200 m), whereas in the upper layers $(0-100 \mathrm{~m})$ they often co-exist at variable ratios with phycoerythrin-rich unicellular cyanobacteria assigned to Synechococcus (see Partensky et al., 1999), a botanical form genus encompassing several distinct genetic clusters (Herdman et al., 1979b; Waterbury \& Rippka, 1989; Urbach et al., 1998; Honda et al., 1999).

Members of the genus Prochlorococcus synthesize divinyl-chlorophyll $a$ and $b\left(a_{2}\right.$ and $\left.b_{2}\right)$ (Goericke \& Repeta, 1993), may contain monovinyl-chlorophyll $b$ (b $\left.b_{1}\right)$ (Partensky et al., 1993; Moore et al., 1995), but lack monovinyl chlorophyll $a\left(a_{1}\right)$ (Goericke \& Repeta, 1993; Partensky et al., 1993; Moore et al., 1995). Minor quantities of a chlorophyll $c$-like pigment
(Mg, 3-8 divinyl phaeoporphyrin $\mathrm{a}_{5}$ ) and $\alpha$-carotene, rather than $\beta$-carotene, are additional characteristic features (Chisholm et al., 1992; Goericke \& Repeta, 1992, 1993). Most isolates lack phycobiliproteins, but the holotype Prochlorococcus marinus CCMP $1375^{\mathrm{T}}$ synthesizes small amounts of a novel phycoerythrin (PE), called PE-III (Hess et al., 1996, 1999). Based on sequence analyses of the respective genes (cpeA and cpe $B$ ), PE-III is distinct both from the common cyanobacterial phycoerythrin, C-PE-I and from PE-II, mainly found in marine cyanobacteria (Ong \& Glazer, 1991; Swanson et al., 1991). However, none of the Prochlorococcus isolates examined, including strain CCMP $1375^{\mathrm{T}}$, contain phycobilisomes (Chisholm et al., 1992; Lichtlé et al., 1995; Hess et al., 1999). Therefore, the cellular location and role of PE-III in the latter strain remains unknown, although a function as a light-harvesting pigment has recently been suggested (Lokstein et al., 1999).

On the basis of their pigment composition and genetic affiliations inferred by $16 \mathrm{~S}$ rRNA sequence analyses, Prochlorococcus isolates have been assigned to a 'lowlight-adapted clade' (LL) and to a 'high-light-adapted clade' (HL) (Urbach et al., 1998; Partensky et al., 1999; West \& Scanlan, 1999). The former is mainly composed of ecotypes originating from deep waters ( $80 \mathrm{~m}$ or more) and exhibiting high chl $b / a_{2}$ ratios (0.4-2.4) (Moore et al., 1995; Urbach et al., 1998). The members of the HL clade are thought to preferentially inhabit the more illuminated surface layers and are characterized by much lower chl $b / a_{2}$ ratios $(<0 \cdot 15)$ (Goericke \& Repeta, 1993; Moore et al., 1995, 1998; Urbach et al., 1998; Partensky et al., 1999). They also differ with respect to light sensitivity, the LL representatives being photoinhibited at irradiances that are optimal for growth of the members of the HL clade (Moore et al., 1995, 1998; Urbach et al., 1998). However, two strains (MIT 9302 from the Sargasso Sea and MIT 9312 from the Gulf Stream) seem to be somewhat exceptional in having a chl $b / a_{2}$ ratio of about $0 \cdot 7$, considered to be typical of the LL clade (see above), but being genetically assignable to the HL clade (Moore et al., 1998). It therefore seems possible that pigment signatures are not always sufficient to predict phylogenetic affiliations among Prochlorococcus isolates or field populations and that the apparent correlation of light penetration in the habitat with pigment phenotype and genotype may be oversimplified. Furthermore, the use of light-harvesting pigments as a discriminatory taxonomic marker requires caution since, as shown for phycobiliproteinrich cyanobacteria (Tandeau de Marsac \& Houmard, 1993; Grossman et al., 1994; Liotenberg et al., 1996), their complement may to be influenced by the nutritional status of the cells. The latter, however, is difficult to assess at present, since all previous studies, including the description of the type species $P$. marinus CCMP $1375^{\mathrm{T}}$, were performed on impure cultures that, depending on their original habitat or degree of contamination, harbour a commensal bacterial flora 
of rather variable metabolic properties which may affect pigment composition. In order to permit defined physiological studies and sequence analyses of a wider range of genes (i.e. beyond those encoding components of the photosynthetic apparatus or the highly conserved $r r n$ genes), we attempted to purify the type strain of the genus Prochlorococcus. In this paper, we report some physiological and genetic properties of $P$. marinus strain PCC 9511, the first axenic isolate. A new subspecies, Prochlorococcus marinus subsp. pastoris, is proposed.

\section{METHODS}

Cyanobacterial strains. The axenic strain PCC 9511, deposited in the Pasteur Culture Collection of Cyanobacteria (PCC, Institut Pasteur, Paris, France) was purified from a primary culture of the genus Prochlorococcus originally designated 'LG' (Palenik \& Haselkorn, 1992; Palenik, 1994) or 'SARG' (Partensky et al., 1993; Morel et al., 1993). It had been kindly provided in 1990 to F. Partensky by L. Moore and S. W. Chisholm (MIT, Cambridge, USA) and was maintained in the Roscoff Culture Collection (France) until 1993, from where it was sent to the principal investigator of the present study. This isolate, rendered axenic in 1995, was first thought to be co-identic with two non-axenic clonal isolates equally derived from ' $L G$ ' and designated 'SSW5' (Urbach et al., 1992) and 'SS120' (Moore et al., 1995). The latter was described as the nomenclatural type, P. marinus, strain CCMP $1375^{\mathrm{T}}$ and deposited in the Provasoli-Guillard National Center for Culture of Marine Phytoplankton (Chisholm et al., 1992). The characterization of strain PCC 9511, however, demonstrated that it is phenotypically and genotypically distinct from the type strain (see Results). Synechococcus PCC 7001, used for comparative photomicroscopy, has been described previously (Rippka et al., 1979).

Growth media. The media employed during this study are shown in Table 1. The slightly modified Gaffron's trace metal solution (Rippka, 1988) used for most of the early media (PCR-S8 to PCR-S16) contained the following $(\mu \mathrm{M})$ : $\mathrm{H}_{3} \mathrm{BO}_{3}$ (300); $\mathrm{MnSO}_{4} . \mathrm{H}_{2} \mathrm{O}(60) ; \mathrm{Na}_{2} \mathrm{WO}_{4} .2 \mathrm{H}_{2} \mathrm{O}(0 \cdot 6)$; $\left(\mathrm{NH}_{4}\right)_{6} \mathrm{Mo}_{7} \mathrm{O}_{24} \cdot 4 \mathrm{H}_{2} \mathrm{O}(0 \cdot 4) ; \mathrm{KBr}(6 \cdot 0) ; \mathrm{KI}(3 \cdot 0) ; \mathrm{ZnSO}_{4}$. $7 \mathrm{H}_{2} \mathrm{O}(6 \cdot 0) ; \mathrm{Cd}\left(\mathrm{NO}_{3}\right) .4 \mathrm{H}_{2} \mathrm{O}(3 \cdot 0) ; \mathrm{Co}\left(\mathrm{NO}_{3}\right)_{2} \cdot 6 \mathrm{H}_{2} \mathrm{O}(3 \cdot 0)$; $\mathrm{CuSO}_{4} \cdot 5 \mathrm{H}_{2} \mathrm{O}(3 \cdot 0) ; \mathrm{NiCl}_{2} \cdot 6 \mathrm{H}_{2} \mathrm{O}(3 \cdot 0) ; \mathrm{Cr}\left(\mathrm{NO}_{3}\right)_{3} \cdot 9 \mathrm{H}_{2} \mathrm{O}$ $\left.(0 \cdot 6) ; \mathrm{VSO}_{5} \cdot 5 \mathrm{H}_{2} \mathrm{O}(0 \cdot 6) ; \mathrm{KAl}_{(} \mathrm{SO}_{4}\right)_{2} .12 \mathrm{H}_{2} \mathrm{O}(6 \cdot 0) ; \mathrm{SeO}_{2}$ (3.0). The trace metal stock solution A5 + Co (Rippka, 1988) for media PCR-SA 6 and PCR-Tu $\mathrm{H}_{2}$ was diluted 10 -fold prior to use. For both trace element solutions, the compounds were dissolved separately in sterile water, mixed, and adjusted to the final volume. The $\mathrm{Na}_{2}$-EDTA/ $\mathrm{FeCl}_{3}$ complex was prepared by dissolving $\mathrm{FeCl}_{3} \cdot 6 \mathrm{H}_{2} \mathrm{O}(270 \mathrm{mg})$ and $\mathrm{Na}_{2}$-EDTA (372 mg) in $10 \mathrm{ml} \mathrm{HCl}(0 \cdot 1 \mathrm{M})$ and $10 \mathrm{ml} \mathrm{NaOH}$ $(0 \cdot 1 \mathrm{M})$, respectively, before mixing and diluting with sterile water to a final volume of $500 \mathrm{ml}$ (Skulberg, 1990). All stock solutions added to the autoclaved seawater were filtersterilized $(0.22 \mu \mathrm{m}$, Millex GP; Millipore) and stored at $4{ }^{\circ} \mathrm{C}$. The recipe of Turks Island Salts solution (Merck Index no. 9954) used for the artificial seawater medium PCR-Tu $\mathrm{T}_{2}$ is as follows (mM): $\mathrm{NaCl}(480) ; \mathrm{MgSO}_{4}(28) ; \mathrm{MgCl}_{2}(27) ; \mathrm{KCl}$ (9); $\mathrm{CaCl}_{2}$ (10). To avoid precipitation, the latter salt was dissolved in 1 vol. $\mathrm{H}_{2} \mathrm{O}$ and added only after all other ingredients had each been dissolved separately in aliquots of a total of 9 vols. The vitamin mix 8A (Table 1) was purchased from Sigma (ref. P 9931), its composition being described by McLachlan (1973).

Growth on solid media. Purification by isolation of single colonies was attempted with several different media (PCRS8, PCR-S11, PCR-S12 and PCR-Tu ${ }_{2}$ ) using different solidifying agents (washed agar A 8678, agarose A6013 and A 9539, Sigma; agarose Litex LSL 4000, FMC) at 0.6 and $0.8 \%(\mathrm{w} / \mathrm{v})$. For the former three seawater-based media, the solidifying agents were dissolved and autoclaved separately in $\mathrm{H}_{2} \mathrm{O}\left(20 \%\right.$ of the final volume), cooled to $50{ }^{\circ} \mathrm{C}$, and then added to 4 vols pre-warmed medium. For the artificial medium PCR-Tu $u_{2}$, both the Turks Island Salts mix and the solidifying agents were prepared at double strength, before mixing equal volumes after sterilization and cooling. The appropriate nutrient supplements were added prior to pouring the plates.

Purification. Based on the known correspondence (R.

Table 1. Media employed for Prochlorococcus PCC 9511

\begin{tabular}{|c|c|c|c|c|c|c|c|}
\hline Components & PCR-S8 & PCR-S10 & PCR-S11 & PCR-S12 & PCR-S16 & PCR-SA 6 & PCR-Tu \\
\hline Seawater (autoclaved) (ml) & 900 & 1000 & 1000 & 1000 & 1000 & 1000 & \\
\hline Seawater (filter-sterilized) (ml) & 100 & & & & & & \\
\hline Turks Island Salt solution* (ml) & & & & & & & 1000 \\
\hline HEPES-NaOH (pH 7.5) (mM) & 1 & 1 & 1 & 1 & 1 & 1 & 1 \\
\hline $\mathrm{NaHCO}_{3}(\mathrm{mM})$ & & & & & & & 2 \\
\hline Trace metals 'Gaffron $+\mathrm{Se}^{*} *\left(\mathrm{ml} \mathrm{l}^{-1}\right)$ & 0.5 & 0.5 & 0.5 & 0.5 & $0 \cdot 05$ & & \\
\hline Trace metals A5 + Co* $\left(\mathrm{ml} \mathrm{l}^{-1}\right)$ & & & & & & 0.5 & 0.5 \\
\hline $\mathrm{Na}_{2}-\beta$-glycerophosphate $(\mu \mathrm{M})$ & 20 & 50 & & & & & \\
\hline $\mathrm{Na}-\mathrm{PO}_{4}(\mathrm{pH} 7 \cdot 5)(\mu \mathrm{M})$ & & & 50 & 50 & 5 & 50 & 50 \\
\hline $\mathrm{Na}_{2}-\mathrm{EDTA} / \mathrm{FeCl}_{3}{ }^{*}(\mu \mathrm{M})$ & 8 & 8 & 8 & 8 & $1 \cdot 6$ & 8 & 8 \\
\hline$\left(\mathrm{NH}_{4}\right)_{2} \mathrm{SO}_{4}(\mu \mathrm{M})$ & 125 & 400 & 400 & 400 & 40 & 400 & 400 \\
\hline Vitamin $B_{12}\left(\mu \mathrm{g}^{-1}\right)$ & 10 & 10 & 10 & & & 10 & 10 \\
\hline Vitamin mix $8 \mathrm{~A} \dagger\left(\mathrm{ml} \mathrm{l}^{-1}\right)$ & & & & 1 & $0 \cdot 1$ & & \\
\hline
\end{tabular}

* Prepared or modified as described in Methods.

$\dagger$ For composition, see McLachlan (1973). 
Rippka, unpublished) of $\mathrm{OD}_{750}(1 \cdot 0)$, cell size (diameter $2.5 \mu \mathrm{m})$, cell volume $\left(8.18 \mu^{3}\right)$ and viable cell counts $\left(2-3 \times 10^{7} \mathrm{ml}^{-1}\right)$ for Synechocystis PCC 6803, it was estimated that an $\mathrm{OD}_{750}=0 \cdot 1$ of Prochlorococcus marinus (cell diameter about $0.5 \mu \mathrm{m}$ ) would correspond to about $2-3 \times 10^{8}$ cells $\mathrm{ml}^{-1}$. Consequently, for the purification of clonal isolates, serial dilutions $\left(10^{-1}-10^{-9}\right)$ were performed in Pyrex test tubes $(18 \mathrm{ml}$ ) containing $7 \mathrm{ml}$ growth media (see Results and Table 1). Dilutions were 10 -fold up to $10^{-8}$, but were twofold in the final range. The tubes were incubated at $18{ }^{\circ} \mathrm{C}$, receiving white light (Osram White Universal White) of a photosynthetic photon flux density (PPFD) of $10 \mu \mathrm{mol}$ quanta $\mathrm{m}^{-2} \mathrm{~s}^{-1}$ (measured with a LICOR LI-185B quantum/radiometer/photometer equipped with a LI190SB quantum sensor) over a light/dark cycle of $14 \mathrm{~h} / 10 \mathrm{~h}$. Every $14 \mathrm{~d}$, loss of liquid by evaporation was compensated for by addition of an appropriate volume of sterile water.

Purity tests. A putative axenic culture, as judged by oil immersion phase-contrast microscopy, was tested for purity on plates of medium ASNIII (Rippka et al., 1979), supplemented with glucose and Casamino acids $(0 \cdot 2$ and $0.02 \%$, respectively) and solidified with Difco Bacto agar (1\%). After several days' incubation in the dark (at $18{ }^{\circ} \mathrm{C}$ and at room temperature), and in contrast to the original impure culture, bacterial growth was not observed. Purity was also confirmed on plates of medium PCR-S11, solidified with Sigma washed agar $(0.8 \%, \mathrm{w} / \mathrm{v})$ and containing $5 \%(\mathrm{v} / \mathrm{v})$ of medium Luria-Bertani (Sambrook et al., 1989), in addition to the aforementioned organic supplements. Finally, the lack of bacterial contaminants was confirmed by experiments in liquid media, testing for the growth-promoting effects of a wide range of different organic compounds (see below).

Growth experiments. The effect of various sources of nitrogen and phosphate or other growth supplements was examined in duplicate or triplicate, and was judged visually by comparison to control cultures lacking the additions. These experiments were performed in test tubes $(18 \mathrm{ml})$ containing $6 \mathrm{ml}$ of the growth medium specified. Incubation was at $20{ }^{\circ} \mathrm{C}$ and fluorescent tubes (Claude/GTE Blanc Industriel) were used to provide a PPFD of $40 \mu \mathrm{mol} \mathrm{m} \mathrm{m}^{-2} \mathrm{~s}^{-1}$ over a light/dark cycle of $14 \mathrm{~h} / 10 \mathrm{~h}$.

Large-scale cultivation. Cell material for the extraction of chromosomal DNA was accumulated over the course of 4 months. For this, the cultures (58 in total) were grown in medium PCR-S11 $(200 \mathrm{ml})$, individually prepared from stock solutions in Erlenmeyer flasks $(500 \mathrm{ml})$, and incubated at $18{ }^{\circ} \mathrm{C}$ under the conditions described for the serial dilutions (see above). The volumes for inoculation (20-30 ml) were adjusted depending on the densities of the pre-cultures, whose growth phase (in the range of $\mathrm{OD}_{750}$ $0 \cdot 10-0 \cdot 15)$ was monitored by measurements in plastic cuvettes (3 ml, $1 \mathrm{~cm}$ light path) in a Kontron Uvikon 860 spectrophotometer. The cells were harvested after 10-14 d by centrifugation for $30 \mathrm{~min}$ at $20^{\circ} \mathrm{C}$ and $6000 \mathrm{~g}$. The resulting pellets, containing a large amount of salt precipitate from the seawater-based medium, were purified by resuspension in $20 \mathrm{ml}$ sterile seawater or $\mathrm{NaCl}(150 \mathrm{mM})$ and centrifugation for $2 \mathrm{~min}$ at $300 \mathrm{~g}$ and $20^{\circ} \mathrm{C}$. The supernatants were recentrifuged for $15 \mathrm{~min}$ at $20000 \mathrm{~g}$. The pellets were collected in $2 \mathrm{ml}$ screwcap microtubes (Sarstedt), centrifuged again for $15 \mathrm{~min}$ and finally stored at $-20{ }^{\circ} \mathrm{C}$ until use.

Ultrastructure. For transmission electron microscopy, cells from a culture $\left(200 \mathrm{ml}, \mathrm{OD}_{750} 0 \cdot 13\right)$ grown under the conditions described for large-scale cultivation (see above) were concentrated by centrifugation and fixed for $90 \mathrm{~min}$ at $4{ }^{\circ} \mathrm{C}$ in glutaraldehyde $(2 \%, \mathrm{v} / \mathrm{v})$ in $0 \cdot 1 \mathrm{M}$ sodium phosphate buffer, $\mathrm{pH} 7 \cdot 2$, containing $0 \cdot 25 \mathrm{M}$ sucrose. Post-fixation was performed for $120 \mathrm{~min}$ with $\mathrm{OsO}_{4}(1 \%$, v/v). After dehydration, the cells were embedded in Spurr medium resin. Sectioning and viewing were performed as described by Lichtlé et al. (1995).

Spectrometry. Absorption spectra were recorded in a Kontron Uvikon 933 spectrophotometer, on cell suspensions $\left(1 \mathrm{ml}, \mathrm{OD}_{750} 0 \cdot 08-0 \cdot 13\right)$ and after concentration of $2 \mathrm{ml}$ by centrifugation $\left(15 \mathrm{~min}\right.$ at $20^{\circ} \mathrm{C}$ and $20000 \mathrm{~g}$ ) and extraction for $30 \mathrm{~min}$ in $1 \mathrm{ml}$ acetone $(90 \%, \mathrm{v} / \mathrm{v})$ at room temperature in the dark. In order to reduce light scattering, in vivo spectra were recorded by substracting the absorbance of a depigmented cell sample, obtained by addition of $20 \mu \mathrm{l}$ household bleach ('Eau de Javel') and incubation for $30 \mathrm{~min}$. Both in vivo and acetone spectra were standardized to represent the absorbance values of cultures $(1 \mathrm{ml})$ of an $\mathrm{OD}_{750}=0 \cdot 1$ and, for the former, the $\mathrm{OD}_{750}$ was substracted. Fluorescence excitation and emission spectra were performed on a 15-fold concentrated cell suspension at room temperature using a Perkin Elmer LS50 spectrofluorometer.

Pigment analyses. For pigment determinations, triplicate samples $(25 \mathrm{ml})$ were filtered on Whatman $\mathrm{GF} / \mathrm{F}$ at very low vacuum pressure $(<5 \mathrm{~mm} \mathrm{Hg})$ and analysed by reversephase HPLC on a Zorbax ODS C18 column $(25 \times 4.6 \mathrm{~cm})$, according to Kraay et al. (1992) with the modifications reported by Garczarek et al. (1998).

Analysis by SDS-PAGE and Western blotting. A polyclonal antiserum to the $\alpha$ subunit of phycoerythrin ( $\alpha$ PE) of Prochlorococcus marinus CCMP $1375^{\mathrm{T}}$ was raised in rabbits by immunization with the recombinant fusion protein expressed in Escherichia coli (Hess et al., 1999). Western blots of Prochlorococcus PCC 9511 were prepared from total protein extracts separated on $15 \%$ SDS-polyacrylamide gels and blotted on PVDF membranes (NEN Life Sciences) using a semi-dry blotter (Bio-Rad). Total proteins of Chamaesiphon PCC 6605, a cyanobacterium that contains high levels of C-phycoerythrin (Bryant, 1982), as well as the $\alpha$ PE recombinant fusion protein of $P$. marinus CCMP $1375^{\mathrm{T}}$, were included as positive controls. Incubation with IgG-purified anti- $\alpha$ PE-serum as a primary antibody was performed at a titre of $1: 600$ for $1 \mathrm{~h}$ at room temperature. The secondary antiserum (anti-rabbit IgG; Sigma) was conjugated with alkaline phosphatase and used at a titre of $1: 8000$. The blots were developed using the chromogenic substrates nitro-blue tetrazolium and 5-bromo-4-chloro-3indolyl phosphate from Sigma.

Mean DNA base composition and genome size. DNA of Prochlorococcus PCC 9511 was extracted from the pooled pellets $(1.75 \mathrm{~g}$ wet $\mathrm{wt})$ and purified on hydroxyapatite as described by Herdman et al. (1979b). The mean DNA base composition $(\mathrm{mol} \% \mathrm{G}+\mathrm{C}$ ) was calculated from the temperature midpoint of denaturation $\left(T_{\mathrm{m}}\right)$ following thermal denaturation of DNA $\left(\mathrm{OD}_{260}\right.$ approx. $0 \cdot 3$ in $0 \cdot 1 \times \mathrm{SSC}, \mathrm{pH}$ $7 \cdot 0 ; \mathrm{SSC}=150 \mathrm{mM} \mathrm{NaCl}, 15 \mathrm{mM}$ sodium citrate), as described by Herdman et al. (1979b), except that a Kontron Uvikon 933 spectrophotometer was employed, in the dualbeam mode. The temperature of the DNA solutions in sealed cuvettes $(1.0 \mathrm{ml}$ total volume, $1 \mathrm{~cm}$ light path) was increased at a rate of $0 \cdot 1^{\circ} \mathrm{C} \mathrm{min}^{-1}$. The reference cuvette contained a solution of guanine $\left(\mathrm{OD}_{260} 0 \cdot 02\right.$ units less than 
that of the DNA) to correct for electronic drift of the instrument and for solvent expansion. The temperature probe of the instrument was calibrated by denaturing cyanobacterial DNA samples of known base composition (Herdman et al., 1979b): Synechocystis sp. PCC 6308, $34.7 \mathrm{~mol} \%$ G $+\mathrm{C}$; Oscillatoria agardhii PCC 7821, $40.0 \mathrm{~mol} \% \mathrm{G}+\mathrm{C} ;$ Arthrospira platensis PCC 7345, $44.3 \mathrm{~mol} \% \mathrm{G}+\mathrm{C}$; Synechocystis sp. PCC 6803, $47.5 \mathrm{~mol} \%$ $\mathrm{G}+\mathrm{C}$; Synechococcus elongatus PCC 6301, 55.1 mol\% $\mathrm{G}+\mathrm{C}$; Cyanobium gracile (previously Synechococcus sp.) PCC $6307,69.7 \mathrm{~mol} \% \mathrm{G}+\mathrm{C}$. The mean $T_{\mathrm{m}}$ of Prochlorococcus strain PCC 9511 DNA was determined in duplicates in three independent denaturation experiments, in which DNA of Synechocystis sp. PCC 6308 was included to control for daily fluctuations in the sensitivity of the temperature probe.

Genetic complexity (genome size) was determined from the kinetics of renaturation of DNA at the optimal temperature of renaturation. DNA was thermally denatured in $0 \cdot 1 \times \mathrm{SSC}$ and the renaturation reaction was initiated by addition of an appropriate pre-warmed volume of $\mathrm{NaCl}$ to bring the final concentration of $\mathrm{Na}^{+}$to $1 \mathrm{M}$ (Herdman et al., 1979a; Schyns et al., 1997). The molecular mass of the genome of Prochlorococcus strain PCC 9511 was calculated from the second-order renaturation rate constant $k_{2}$, determined as described by Schyns et al. (1997), and by reference to that of cyanobacteria of known genetic complexity (Herdman et al., 1979a).

Analysis by PFGE. Inclusions for PFGE analyses were performed by modification of a protocol described by Churin et al. (1995). Cells $(250 \mathrm{ml}$ of a culture containing approx. $10^{8}$ cells $\mathrm{ml}^{-1}$ ) were concentrated by centrifugation, transferred to Eppendorf microtubes and washed twice in $2 \mathrm{ml}$ diluted seawater $(50 \%, \mathrm{v} / \mathrm{v}$, and $20 \%, \mathrm{v} / \mathrm{v}$, for the first and second wash, respectively), supplemented with $50 \mathrm{mM}$ EDTA, pH 8.0. The pellet was resuspended in $1 \mathrm{ml}$ of the second washing solution and embedded by mixing with an equal volume of low-melting-point agarose $(1.2 \%, \mathrm{w} / \mathrm{v}$; BRL), dissolved in $50 \mathrm{mM}$ EDTA, $\mathrm{pH} 8.0$ and equilibrated to $50{ }^{\circ} \mathrm{C}$. After immediate transfer into plug formers, the agarose inclusions were hardened consecutively at room temperature $(0 \cdot 5-1 \mathrm{~h})$ and at $4{ }^{\circ} \mathrm{C}(0 \cdot 5-1 \mathrm{~h})$. They were then cut into pieces $\left(5 \times 8 \mathrm{~mm}^{2}\right)$ and digested for $16 \mathrm{~h}$ at $55^{\circ} \mathrm{C}$ with proteinase $\mathrm{K}(0.1 \%$ in a total volume of $5 \mathrm{ml} 0.5 \mathrm{M}$ EDTA, pH $8 \cdot 0$, containing $1 \%$, w/v, SDS). Subsequently the agarose plugs were washed three times in TE $(10 \mathrm{mM}$ Tris $/ \mathrm{HCl}, 1 \mathrm{mM}$ EDTA, $\mathrm{pH} 8 \cdot 0$ ) and twice in TE supplemented with fresh PMSF for $30 \mathrm{~min}$ each. Prior to use and equilibration in the appropriate restriction enzyme buffer, samples were washed again three times in TE. Restriction was performed overnight at $37^{\circ} \mathrm{C}\left(\right.$ MluI, Not I ) or at $25^{\circ} \mathrm{C}$ (SmaI). Separation of restriction fragments was performed with a CHEF-MAPPER (contour-clamped homogeneous field electrophoresis; Bio-Rad Laboratories) in $1 \%$ agarose gels in $0.5 \times$ TBE (Sambrook et al., 1989) at a temperature of $13.8{ }^{\circ} \mathrm{C}$, using the auto algorithm option. The exact conditions for the separation of fragments in the range $5-30 \mathrm{kbp}$ were $9.0 \mathrm{~V} \mathrm{~cm}^{-1}$ for the forward voltage gradient and $6.0 \mathrm{~V} \mathrm{~cm}^{-1}$ for the reverse voltage gradient. The initial swap time was $0 \cdot 11 \mathrm{~s}$, the final swap time $0.46 \mathrm{~s}$. For the separation of fragments in the range $30-300 \mathrm{kbp}$, the voltage gradient was $6 \mathrm{~V} \mathrm{~cm}^{-1}$ throughout, and the initial and final swap times were $2 \cdot 16$ and $26 \cdot 29 \mathrm{~s}$, respectively. After the run was complete, the bands were stained with ethidium bromide $\left(1 \mu \mathrm{g} \mathrm{ml}^{-1}\right)$ and photographed by a UVP Image Store 7500 System.
Determination of 16S rRNA gene sequences. The 16S rRNA gene of Prochlorococcus PCC 9511 was amplified by PCR in a Perkin-Elmer Cetus Gene Amp 9600 Thermal Cycler, using chromosomal DNA prepared from cultures $(25-50 \mathrm{ml})$ grown to an $\mathrm{OD}_{750}$ of about $0 \cdot 05-0 \cdot 1$, as described by Cai \& Wolk (1990). The reactions were performed in $500 \mu \mathrm{l}$ microtubes (MoBiTec) containing the following: $10 \mu \mathrm{l}$ of $10 \times$ Taq polymerase buffer (Appligène); $10 \mu \mathrm{l}$ dNTP

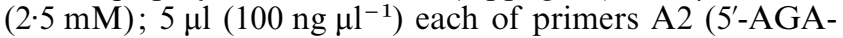
GTTTGATCCTGGCTCAG-3') and S17 (5'-GGCTACCTTGTTACGAC-3') (E. coli numbering 8-27 and 1494-1510, respectively, Ruimy et al., 1994); $200 \mathrm{ng}$ of Prochlorococcus chromosomal DNA and 5 U Taq polymerase (Appligène). The volumes were adjusted to $100 \mu \mathrm{l}$ with sterile high-purity $\mathrm{H}_{2} \mathrm{O}$. The thermal cycling profiles and cycle numbers were: one cycle of denaturation $\left(95^{\circ} \mathrm{C}\right)$ for $3 \mathrm{~min}$, annealing at $51^{\circ} \mathrm{C}$ for $2 \mathrm{~min}$ and extension at $72{ }^{\circ} \mathrm{C}$ for $30 \mathrm{~s} ; 25$ cycles at $94{ }^{\circ} \mathrm{C}(30 \mathrm{~s}), 51^{\circ} \mathrm{C}(2 \mathrm{~min})$ and $72{ }^{\circ} \mathrm{C}(1.5 \mathrm{~min})$; final cycle of $94^{\circ} \mathrm{C}(30 \mathrm{~s}), 51^{\circ} \mathrm{C}(1 \mathrm{~min})$ and $72{ }^{\circ} \mathrm{C}(5 \mathrm{~min})$, followed by storage at $10^{\circ} \mathrm{C}$. The PCR products were analysed for the expected size (about $1450 \mathrm{bp}$ ) by gel electrophoresis, purified using the Wizard PCR PREPS DNA purification system (Promega), and cloned into the plasmid pGEM-T (Promega) as suggested by the manufacturer. Transformation into E. coli $\mathrm{DH} 5 \alpha$ was performed by electroporation (Bio-Rad Gene Pulser II, Pulse Controller PLUS module) following the procedures provided in the manual. Extraction of plasmid DNA from 12 pooled clones was performed with the kit Nucleobond (Macheray-Nagel). Sequences were determined manually for both strands using the T7 sequencing kit (Promega) and the primers described by Ruimy et al. (1994). They were reconfirmed by automatic sequencing (Genome Express). The complete $3^{\prime}$ end of the $16 \mathrm{~S}$ rRNA was determined after amplification and sequencing of the intergenic transcribed spacer (ITS) of the rrn operon using primers $322\left(5^{\prime}\right.$ TGTACACACCGCCCGTC-3') and 340 (5'-CTCTGTGTGCCTAGGTATCC-3'), complementary to regions near the $3^{\prime}$ end of the 16S rRNA and the $5^{\prime}$ end of the 23S rRNA genes, respectively (Willmotte et al., 1993; Iteman et al., 1999). The 16S rRNA sequences of Prochlorococcus strain NATL1 and CCMP 1426 (Partensky et al., 1993; Morel et al., 1993; Scanlan et al., 1996) were determined as described previously (Urbach et al., 1998).

Phylogenetic analyses. Sequences of $16 \mathrm{~S}$ rRNA were obtained from GenBank under the following accession numbers: Cyanobium gracile (previously Synechococcus sp.) PCC 6307, AF001477; Prochlorococcus marinus CCMP 1375 ${ }^{\mathrm{T}}$ X63140; Prochlorococcus marinus CCMP 1378, AF001466; Prochlorococcus sp. GP2, AF001472; Prochlorococcus sp. MIT 9107, AF001468; Prochlorococcus sp. MIT9302, AF053396; Prochlorococcus sp. MIT9303, AF053397; Prochlorococcus sp. MIT9312, AF053398; Prochlorococcus sp. MIT9313, AF053399; Prochlorococcus sp. NATL2, AF001470; Prochlorococcus sp. NATL2A, AF001467; Prochlorococcus sp. PAC1, AF001471; Prochlorococcus sp. SB, AF001473; Prochlorococcus sp. TATL1A, AF001474; Prochlorococcus sp. TATL1B, AF001475; Prochlorococcus sp. TATL2, AF001476; Synechococcus sp. Biwa-B0, D50614; Synechococcus sp. Biwa-G0, D50615; Synechococcus sp. Biwa-P0, D50616; Synechococcus elongatus PCC 6301, X01296, X01982 and X03538; Synechococcus sp. PCC 7001, AB015058; Synechococcus $\mathrm{sp}$. WH 7805, AF001478; Synechococcus sp. WH 8101, AF001480; Synechococcus sp. WH 8103, AF001479; uncultured Clone 100, M63813; uncultured Clone 139, 
M63814; uncultured SARG6, X52169; uncultured SARG7, X52171. The sequences of strains PCC 9511, CCMP 1426 and NATL1 have been deposited in GenBank with the accession numbers AF180967, AF133833 and AF133834, respectively.

The sequences were aligned, in the ARB program (http: //www.mikro.biologie.tu-muenchen.de/pub/ARB), with the PCC database that now contains 315 cyanobacterial 16S rRNA sequences. Phylogenetic trees were inferred with distance matrix methods in the PHYLIP package (Felsenstein, 1993) and by fastDNAml (Olsen et al., 1994), excluding regions that either carried gaps in more than $50 \%$ of the sequences, or where precise alignment was doubtful. The tree shown was inferred with fastDNAml and is consistent with the other methods used; it was extracted from a larger tree based on approximately 110 complete (or almost) cyanobacterial sequences in order to avoid artefacts in branching order that arise when a limited data set is employed (M. Herdman, unpublished results).

\section{RESULTS}

\section{Purification and growth properties}

The impure culture Prochlorococcus strain SARG (see Methods) was initially cultivated in medium $\mathrm{K} / 10-\mathrm{Cu}$ (Chisholm et al., 1992). However, the maximal cell densities obtained even near the stationary phase of growth were too low to be measurable by spectroscopy without concentrating the cultures. Consequently, new growth media were developed and tested. Growth of the impure strain proved superior in media PCR-S8, PCR-S10, PCR-S11 and PCR-S12 (see Table 1), in the latter three giving rise to lemon-green suspensions of optical densities $\left(\mathrm{OD}_{750}\right)$ of $0 \cdot 1-0 \cdot 15$. However, purification attempts by classical streaking techniques on plates prepared with these media, using different solidifying agents (see Methods) proved unsuccessful. If growth was achieved, single colonies were only observed after several months in the heavily contaminated parts of the plates. Therefore we attempted purification by serial dilution in PCR-S8, PCR-S10 and PCR-S11 liquid media, choosing a range of dilutions appropriate for the expected initial number of cells $\left(1-4 \times 10^{8}\right.$ cells $\left.\mathrm{ml}^{-1}\right)$ based on cell size and volume. However, growth at higher dilutions $\left(>10^{-5}\right)$ proved inconsistent and, if observed, only occurred in tubes still harbouring one or more of the commensal bacterial contaminants. Eventually, after many independent attempts, microscopic inspection of a culture derived from a $2 \times 10^{8}$-fold dilution in medium PCR-S12 revealed that it contained Prochlorococcus, accompanied by a common laboratory contaminant (a yellow sarcina forming mucilaginous aggregates and exhibiting relatively large cells), but lacked the small marine bacteria typical of the original impure culture. This suggested that the contaminant had modified the medium by some unknown means (e.g. detoxification) to permit growth of the initial single cell theoretically expected in the range of $1-4 \times 10^{8}$-fold dilutions. The fortuitously large cell size of the contaminant allowed further purification attempts by selective elimination. For this, a culture was centrifuged $(3 \times)$ at low speed
$(300 \mathrm{~g})$, and the final supernatant was diluted $\left(10^{-1}-10^{-3}\right)$ in two different media, PCR-S12 and PCR-S16 (Table 1), with and without the addition of either glutamine $(50 \mu \mathrm{M})$ or methionine $(50 \mu \mathrm{M})$. Microscopic examination of all cultures resulting from these dilutions suggested the purity of one of them, raised in medium PCR-S16 and supplemented with glutamine. This was confirmed by extensive purity tests (see Methods). The axenic isolate entered the Pasteur Culture Collection of Cyanobacteria under strain number PCC 9511 and is also available from the American Type Culture Collection, Manassas, VA, USA (ATCC 700925).

Experiments comparing growth of the axenic strain PCC 9511 in media PCR-S16, PCR-S11, PCR-S12, with or without glutamine $(50 \mu \mathrm{M})$, revealed neither a beneficial effect of Provasoli's vitamin 8A supplements nor an obligate requirement for the amino acid. Thus, the successful isolation of the axenic strain in the more nutrient-poor medium PCR-S16 (see Table 1), containing vitamin mix 8A and glutamine, was coincidental. Since growth yields in medium PCR-S11 were superior to those obtained in medium PCR-S16, the former was initially chosen as the maintenance medium for the axenic strain (but see below). In this medium Prochlorococcus PCC 9511 reaches an $\mathrm{OD}_{750}$ of $0 \cdot 1-0 \cdot 15$ (corresponding to about $3-4 \times 10^{8}$ cells ml $^{-1}$ ) within $10-14 \mathrm{~d}$ from an initial $\mathrm{OD}_{750}$ of about $0 \cdot 01$, if incubated at $20^{\circ} \mathrm{C}$ and receiving a PPFD of $40 \mu \mathrm{mol}$ $\mathrm{m}^{-2} \mathrm{~s}^{-1}$ over a light/dark cycle of $14 \mathrm{~h} / 10 \mathrm{~h}$. The mean growth constant $(\mu)$ was in the range $0 \cdot 23-0 \cdot 3 \mathrm{~d}^{-1}$.

\section{Sources of phosphate}

In the absence of phosphate, cultures of strain PCC 9511 ceased to grow upon the third transfer, whereas replacement of $\mathrm{Na}_{-} \mathrm{PO}_{4}(\mathrm{pH} 7 \cdot 5)$ in medium PCR-S11 by $\mathrm{Na}_{2} \beta$-glycerophosphate, $\mathrm{Na}_{4}$-pyrophosphate, glucose 6-phosphate and ATP at equimolar concentrations $(100 \mu \mathrm{M})$ resulted in good growth rates and yields over the same period of subculturing. These observations indicate that Prochlorococcus is capable of synthesizing one or more phosphohydrolysing enzymes.

\section{Sources of combined nitrogen}

Replacement of ammonia in medium PCR-S11 by urea, nitrate, nitrite, arginine, glutamine and glutamate, at the same concentration $(400 \mu \mathrm{M})$, resulted in comparable growth only with urea, whereas the other compounds gave rise to culture densities similar to controls that lacked a source of combined nitrogen. Urea has been used as the standard source of nitrogen for impure cultures of Prochlorococcus (Chisholm et al., 1992; Partensky et al., 1993), but urease activity of these oxyphototrophs, rather than of the commensal bacterial contaminants, could only be deduced reliably with the axenic strain. 


\section{Effect of diverse compounds on growth}

In an attempt to increase the growth rates and yields, or to discover stimulatory factors eventually permitting growth of single colonies on solid media, a variety of additions were tested in PCR-S11. The following compounds $(100 \mu \mathrm{M})$ are tolerated by Prochlorococcus PCC 9511, but have no beneficial effect: glycine, proline, glutamine, arginine, tryptophan, methionine, dehydroascorbate, glutathione (oxidized), thiosulphate, uracil, thymine, $\delta$-aminolaevulinic acid, salicylic acid and $p-\mathrm{OH}$ benzoate. Difco yeast extract $\left(10 \mu \mathrm{g} \mathrm{ml}^{-1}\right)$, Sigma yeast concentrate $\left(100 \mu \mathrm{g} \mathrm{ml}^{-1}\right)$, putrescine, spermine and cAMP (all $50 \mu \mathrm{M})$, haeminchloride and $\alpha$-lipoic acid $\left(0 \cdot 1\right.$ and $\left.1 \mu \mathrm{g} \mathrm{ml}^{-1}\right)$ and $\mathrm{NaHCO}_{3}(1 \mathrm{mM})$ were equally without effect. In contrast, ferulic acid (50 and $100 \mu \mathrm{M})$, adenine and ascorbate $(10 \mu \mathrm{M})$ inhibited growth. Na-pyruvate $(5 \mathrm{mM})$, glucose, fructose and sucrose $(10 \mathrm{mM})$ were tolerated and seemed to slightly prolong survival, but had no major beneficial effect on the growth rates or yields.

\section{Chromatic light}

Using the coloured filters described by Tandeau de Marsac \& Houmard (1988), growth of the axenic strain was observed in red, but not in green, light. These results are in agreement with the observed lack of phycoerythrinoid light-harvesting antennae (see below).

\section{Trace metals and development of a synthetic seawater medium}

Given the rather low concentration of the trace metal additions in medium PCR-S11 compared to the elements present in natural seawater (Bruland, 1983), it seemed possible that some of the trace metal supplements may not be necessary. Indeed, medium PCR-SA 6 , a modification of medium PCR-S11 in which Gaffron's + Se trace metal solution (see Methods and Table 1) was replaced by a 10 -fold dilution of trace metals A5 + Co (composed of only six rather than 16 trace metals, see Methods), gave growth rates and yields comparable to those typically observed in medium PCR-S11 (see above). For refined physiological studies, a synthetic seawater medium of a more defined composition seemed desirable. Consequently, the natural seawater in medium PCR-SA 6 was replaced by a solution of Turks Island Salts (see Methods and Table 1). This resulted in equivalent growth in both media, provided that $\mathrm{NaHCO}_{3}(2 \mathrm{mM})$ was added to raise the $\mathrm{pH}$ of the artificial salt mix from about 5 to 7·8. With the latter medium, designated PCR-Tu (see $^{2}$ Table 1), it was shown that vitamin $\mathrm{B}_{12}$, routinely added to all previous media, was not essential, since no growth limitation occurred even after 10 successive transfers in the absence of this supplement. The addition to medium PCR-Tu $\mathrm{Tu}_{2}$ of boron (10 and $100 \mu \mathrm{M})$, manganese (1, 10 and $20 \mu \mathrm{M})$, molybdenum

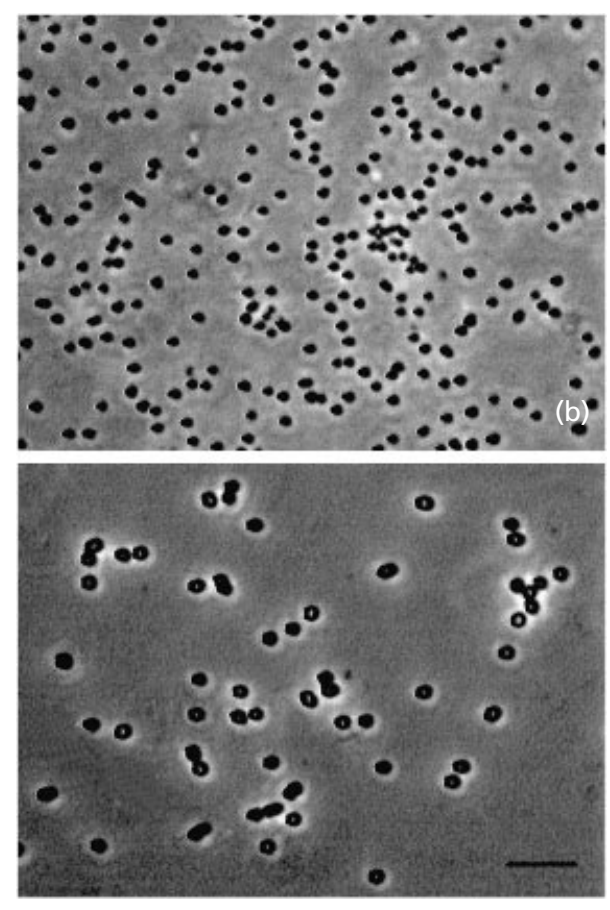

Fig. 1. Light micrographs of Prochlorococcus PCC 9511 (a) and Synechococcus PCC 7001 (b). Bar, $5 \mu \mathrm{m}$.

(1 and $20 \mu \mathrm{M})$, zinc $(1 \mu \mathrm{M})$, nickel $(1 \mu \mathrm{M})$ and selenium $(1 \mu \mathrm{M})$ had no effect, whereas zinc $(10 \mu \mathrm{M})$ and cobalt $(1 \mu \mathrm{M})$ totally inhibited growth. Copper, toxic to some marine cyanobacteria (Waterbury \& Willey, 1988), was only tested and tolerated at $100 \mathrm{nM}$. Finally, the total omission of copper in medium PCR$\mathrm{Tu}_{2}$ resulted in sustained growth comparable to controls $(\mathrm{Cu}=16 \mathrm{nM}$, see Methods) for more than eight successive transfers, demonstrating a lack of, or only low, copper requirement, possibly being met by impurities introduced by the major salts of this artificial seawater medium. The latter result confirms previous studies (Chisholm et al., 1992), performed on impure strains. Lack of growth in medium PCR-Tu with nitrate as sole source of nitrogen, both in the presence and absence of additional molybdenum (5 and $50 \mu \mathrm{M}$ ), reconfirmed earlier observations in medium PCR-S11 (see above). This suggests that the axenic strain is either deficient in a nitrate transport system or does not possess nitrate/nitrite reductase activity.

\section{Morphology and ultrastructure}

Prochlorococcus PCC 9511 exhibited small spherical post-divisional cells, about $0 \cdot 5-0 \cdot 6 \mu \mathrm{m}$ in diameter and about $0.7-0.8 \mu \mathrm{m}$ in length, that in contrast to the marine Synechococcus sp. PCC 7001 were barely visible by light microscopy (Figs 1a, b). Pre-divisional cells were elongated, reaching about $1.2 \mu \mathrm{m}$ in length (Fig. 2). The ultrastructural features of strain PCC 9511 


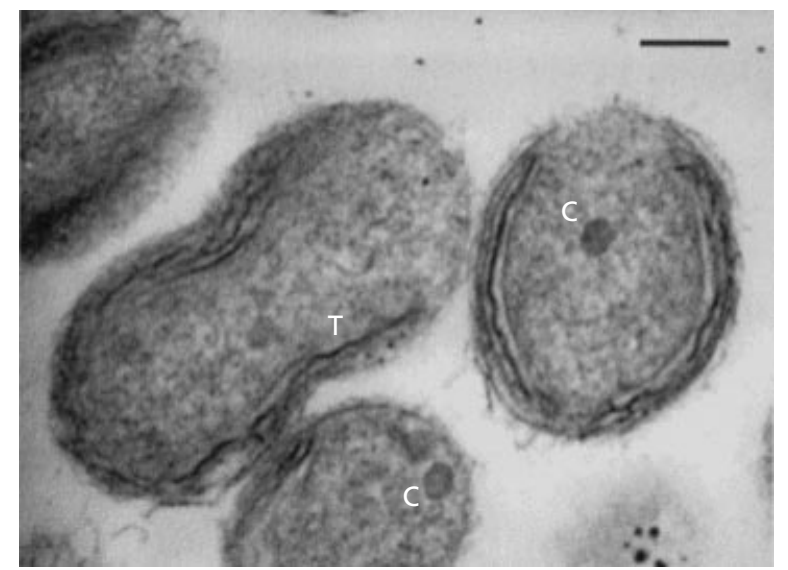

Fig. 2. Transmission electron micrograph of a thin section of Prochlorococcus PCC 9511. C, carboxysomes; T, thylakoids. Bar, $200 \mathrm{~nm}$.

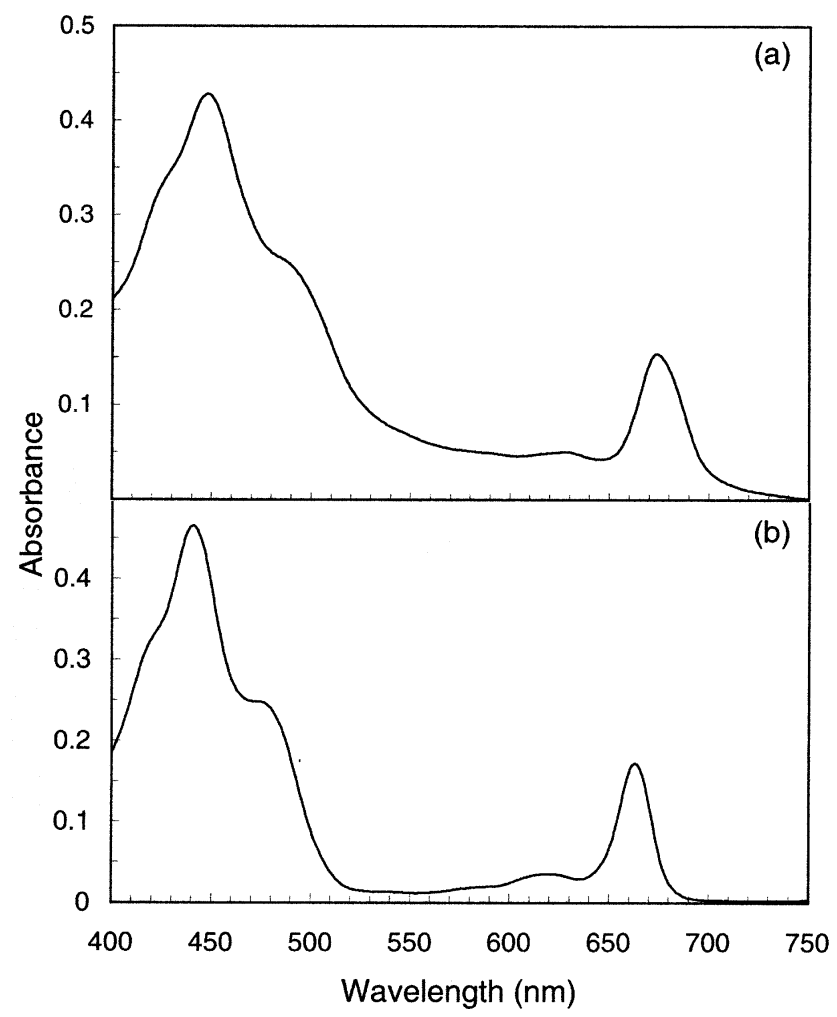

Fig. 3. In vivo absorption spectrum of whole cells after growth in white light at a PPFD of $30 \mu \mathrm{mol} \mathrm{m} \mathrm{m}^{-2} \mathrm{~s}^{-1}$ (a), and absorption spectrum of an acetone extract (b) prepared from the same culture.

revealed an organization typical of prokaryotes with a Gram-negative cell wall (Fig. 2). Carboxysomes, mainly composed of ribulose 1,5-bisphosphate carboxylase/oxygenase and carbonic anhydrase (Kaplan et al., 1994), two enzymes involved in $\mathrm{CO}_{2}$ fixation via

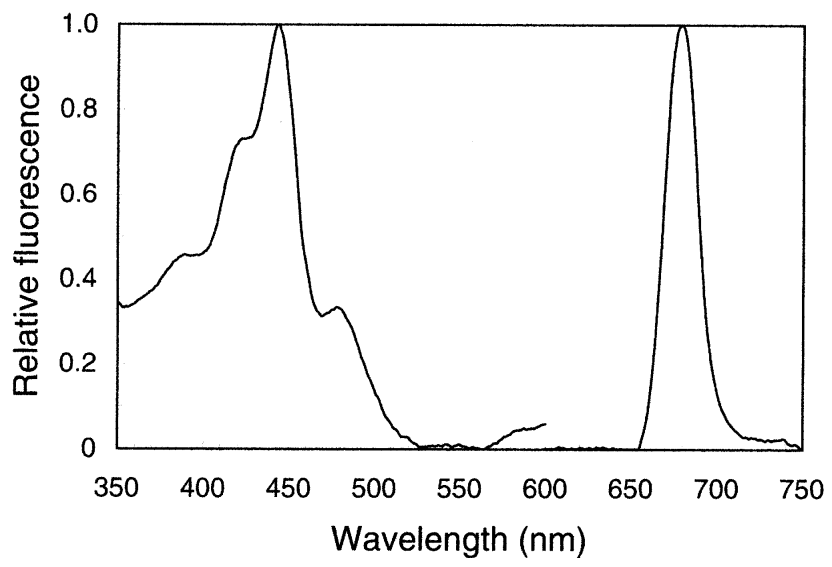

Fig. 4. In vivo fluorescence excitation and emission spectra at room temperature of whole cells of Prochlorococcus PCC 9511 after growth in white light (PPFD $30 \mu \mathrm{mol} \mathrm{m}^{-2} \mathrm{~s}^{-1}$ ). The emission spectrum shown was obtained by excitation at $443.5 \mathrm{~nm}$, and is identical to that with excitation at $478.5 \mathrm{~nm}$.

the reductive pentose phosphate cycle, were also observed. The thylakoid disposition was similar to that of Prochlorococcus strains CCMP 1378 (Lichtlé et al., 1995) and MIT 9313 (see Partensky et al., 1999), representing an interruption of the internal photosynthetic membranes at one cell pole ('horseshoe' arrangement) (Fig. 2). This is in contrast to the holotype strain $\mathrm{CCMP} 1375^{\mathrm{T}}$ which has a concentric thylakoid arrangement (Chisholm et al., 1992; Lichtlé et al., 1995).

\section{Absorption and fluorescence spectra}

Cell suspensions of strain PCC 9511, cultivated in white light $\left(30 \mu \mathrm{mol} \mathrm{m} \mathrm{m}^{-2} \mathrm{~s}^{-1}\right)$, exhibited an in vivo absorption spectrum with a blue maximum at $447 \mathrm{~nm}$ and a red maximum at $674 \mathrm{~nm}$ (Fig. 3a). The spectral profile was similar to that reported for Prochlorococcus CCMP 1378, an isolate containing chl $a_{2}$ and synthesizing only low amounts of chl $b_{2}$ (Morel et al., 1993; Partensky et al., 1993; Moore et al., 1995) but differs from the holotype CCMP $1375^{\mathrm{T}}$. An absorption spectrum of an acetone extract of the same culture of Prochlorococcus PCC 9511 is shown in Fig. 3(b). The three maxima at 441, 620 and $663 \mathrm{~nm}$ correspond with minor shifts to the reported Soret bands of chl $a_{2}$, the shoulder around $475 \mathrm{~nm}$ being attributable to the combined absorption by $\mathrm{chl} b_{2}$ and carotenoids (Morel et al., 1993; Partensky et al., 1993; Moore et al., 1995).

Typical room temperature fluorescence excitation and emission spectra of whole cells of Prochlorococcus PCC 9511 are shown in Fig. 4. As expected for members of this genus (Moore et al., 1995; Partensky et al., 1997), the in vivo fluorescence emission peak was located at $678.5 \mathrm{~nm}$, and the presence of chlorophylls $a_{2}$ and $b_{2}$ is evidenced by fluorescence excitation peaks at $443.5 \mathrm{~nm}$ and $478.5 \mathrm{~nm}$, respectively, both being red 
Table 2. Pigment content (fg cell ${ }^{-1}$ ) of Prochlorococcus PCC 9511 grown at different irradiance values

\begin{tabular}{|lccccccc|}
\hline Irradiance* $^{*}$ & Cells $\mathbf{~ m l}^{-\mathbf{1}}$ & chl $\boldsymbol{a}_{\mathbf{2}}$ & chl $\boldsymbol{b}_{\mathbf{2}}$ & chl $\boldsymbol{c}$-like & Zeaxanthin & $\boldsymbol{\alpha}$-Carotene & chl $\boldsymbol{b}_{\mathbf{2}} / \mathbf{c h l} \boldsymbol{a}_{\mathbf{2}}$ \\
\hline 8 & $3 \cdot 9 \times 10^{8}$ & $1 \cdot 234$ & $0 \cdot 061$ & $0 \cdot 029$ & 0.645 & $0 \cdot 235$ \\
30 & $3 \cdot 2 \times 10^{8}$ & $1 \cdot 151$ & 0.062 & $0 \cdot 026$ & $0 \cdot 739$ & $0 \cdot 204$ \\
80 & $2 \cdot 6 \times 10^{8}$ & $0 \cdot 680$ & $0 \cdot 012$ & $0 \cdot 006$ & $0 \cdot 740$ & $0 \cdot 116$ \\
\hline
\end{tabular}

* PPFD ( $\mu$ mol quanta $\left.\mathrm{m}^{-2} \mathrm{~s}^{-1}\right)$.

shifted by $9 \mathrm{~nm}$ with respect to chlorophylls $a_{1}$ and $b_{1}$ (F. Partensky, unpublished). The large difference in the heights of these two fluorescence excitation peaks is in agreement with the low divinyl-chlorophyll $b$ to $a$ ratio anticipated from the absorption spectra (see above). In contrast, fluorescence excitation due to chl $b_{2}$ absorption was higher in the holotype CCMP $1375^{\mathrm{T}}$ and, at low growth irradiances, exceeded that of chl $a_{2}$ (Moore et al., 1995).

\section{Quantitative determinations of chlorophylls and carotenoids}

Prochlorococcus PCC 9511, grown at various irradiances $\left(8,30\right.$ and $\left.80 \mu \mathrm{E} \mathrm{m}^{-2} \mathrm{~s}^{-1}\right)$, contained chl $a_{2}$, chl $b_{2}$ and traces of a chlorophyll $c$-like pigment (Table 2), but no monovinyl-chlorophyll $b$. Zeaxanthin and $\alpha$ carotene were the only carotenoids detected in the axenic strain. Therefore the traces of unknown carotenoids reported for other non-axenic members of this genus (Chisholm et al., 1988, 1992) are either strain specific or may be attributable to bacterial contaminants. In agreement with the absorption and fluorescence spectra (Figs 3a, b and 4), the chl $b_{2} / \operatorname{chl} a_{2}$ ratios were very low (less than $0 \cdot 1$ ) under all light conditions. This pigment complement resembled that reported for Prochlorococcus CCMP 1378 but differed from that of the holotype CCMP $1375^{\mathrm{T}}$ which, in addition to the former pigments, contained small amounts of chl $b_{1}$ (Partensky et al., 1993; Morel et al., 1993; Moore et al., 1995) and exhibited a ratio of total chlorophyll $b$ (chlorophylls $b_{1}$ plus $b_{2}$ ) over chl $a_{2}$ in the range of 0.4-2.4 (Moore et al., 1995; Urbach et al., 1998).

\section{Search for phycoerythrin}

Western blots were performed using a polyclonal antiserum obtained by aid of a recombinant fusion protein of the cloned $\alpha$ PE-III of strain CCMP $1375^{\mathrm{T}}$ after expression in E. coli (Hess et al., 1999). A band of an apparent molecular mass of about $15 \mathrm{kDa}$ was revealed (Fig. 5) in extracts of Prochlorococcus marinus CCMP $1375^{\mathrm{T}}$ and for the recombinant $\alpha$ PE-III, released from the fusion protein by cleavage with factor X (Hess et al., 1999). This result was in good agreement with the molecular mass of $17 \cdot 3 \mathrm{kDa}$,

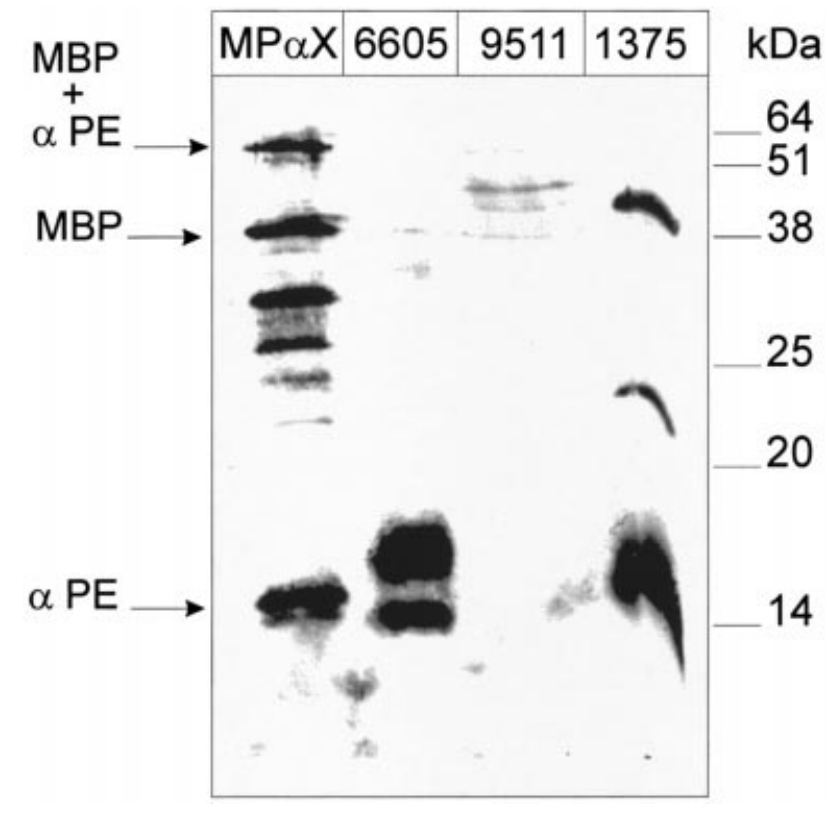

Fig. 5. Immunoblot for detection of phycoerythrin. An antiserum against the $\alpha$-subunit of phycoerythrin of Prochlorococcus CCMP $1375^{\top}$, was cross used to develop a Western blot containing crude extracts of Prochlorococcus PCC 9511, Prochlorococcus CCMP $1375^{\top}$ and Chamaesiphon PCC 6605. The recombinant fusion protein (MP- $\alpha \mathrm{X})$, cleaved after purification by factor $X$ and resulting in release of $\alpha$ PE and the maltosebinding protein (MBP) part from E. coli used for expression, was included as a positive control. Only the recombinant protein and strains known to synthesize PE (PCC 6605 and CCMP 1375') show strong immunodecoration of bands with an appropriate molecular mass.

estimated on the basis of the $\alpha$ PE gene sequence (Hess et al., 1996). Two major polypeptides of about 14 and 18 kDa were recognized in Chamaesiphon PCC 6605, a PE-I containing cyanobacterium that adapts chromatically (Bryant, 1982) and assembles typical phycobilisomes (Waterbury \& Stanier, 1977). Whereas the $14 \mathrm{kDa}$ band remains to be identified (possibly a degradation product), the subunit of $18 \mathrm{kDa}$ corresponds well to the molecular mass deduced by SDSPAGE for other cyanobacterial $\alpha$ PEs (Bogorad, 1975; Alberte et al., 1984). In contrast, no PE was detectable in Prochlorococcus PCC 9511 (Fig. 5). This was 


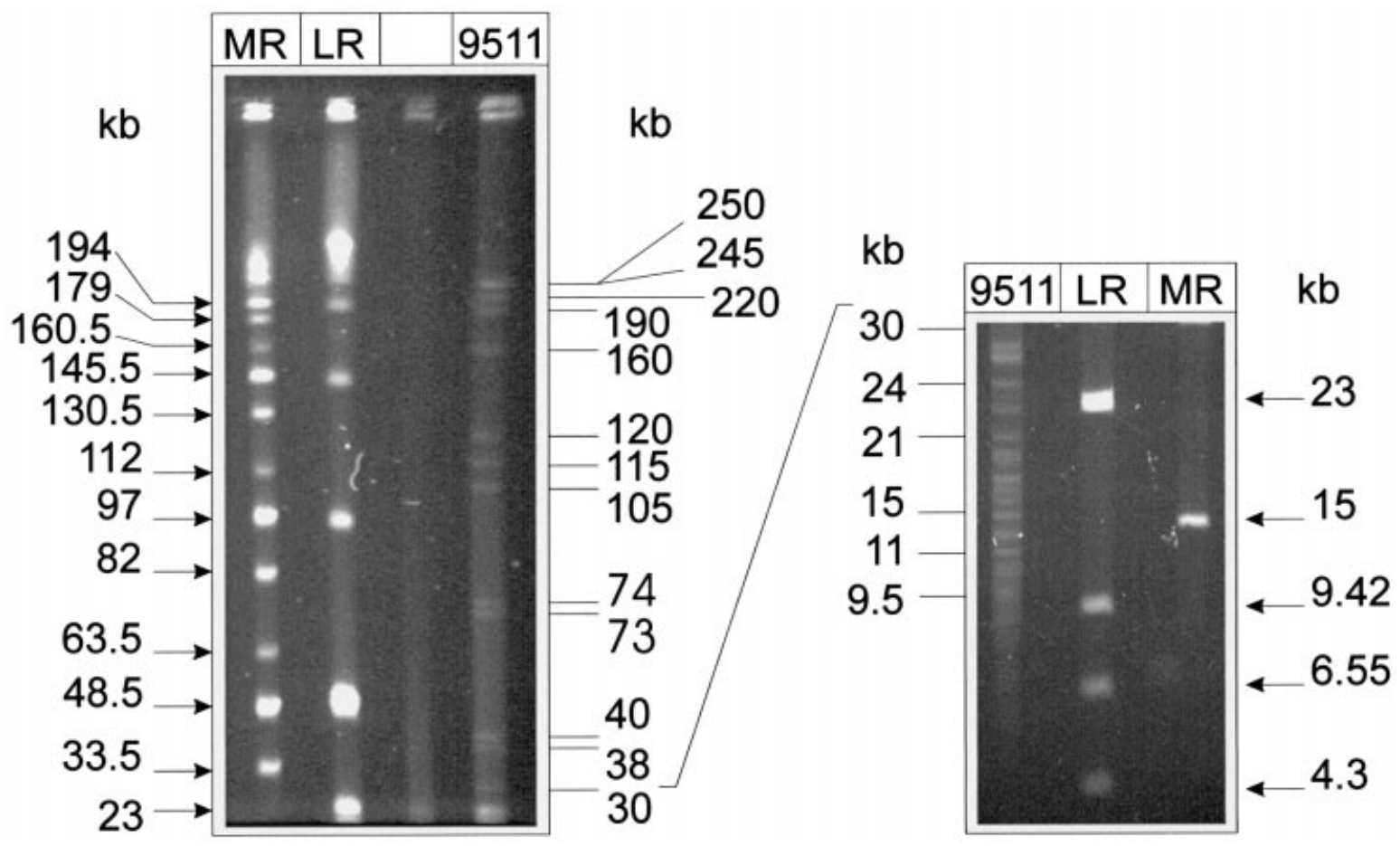

Fig. 6. PFGE analysis. Cells of Prochlorococcus PCC 9511 were included in agarose followed by overnight restriction with the enzyme Mlul and separation of the resulting fragments by contour-clamped homogeneous field electrophoresis. The left panel shows resolution of 12 large bands (molecular mass 30-250 kb); the right panel shows resolution of bands of less than $30 \mathrm{~kb}$. The run was performed using parameter settings appropriate for the respective size range to be separated (see Methods). Mid Range I (MR) and Low Range (LR) PFG Marker from New England Biolabs served as molecular mass markers.

confirmed by PCR studies and Southern blot hybridizations, neither of which revealed the corresponding gene (data not shown).

\section{Genetic characterization}

Prochlorococcus PCC 9511 was shown to have a low mean DNA base composition $(32 \cdot 0 \pm 0 \cdot 1 \mathrm{~mol} \% \mathrm{G}+\mathrm{C})$ and the smallest genome $(1 \cdot 30 \pm 0 \cdot 11 \mathrm{GDa}=2 \mathrm{Mbp}$, determined from DNA renaturation kinetics) of all known oxyphotobacteria. PFGE analyses (Fig. 6) after digestion of chromosomal DNA by the restriction endonuclease $M l u \mathrm{I}$ resulted in 13 bands larger or equal to $30 \mathrm{kbp}$ that could be easily identified (size of individual bands in kbp: 250, 245, 220, 190, 160, 120, $115,105,74,73,40,38,30 ; \Sigma 1660)$. The number of bands $<30 \mathrm{kbp}$ was about 20 . The following sizes (in $\mathrm{kbp}$ ) may be deduced: $28,27 \cdot 5,26,25 \cdot 5,24,23,21$, $19,18,17$ (2 x) $16 \cdot 5,16,15 \cdot 5,13,11,10 \cdot 5,10,9 \cdot 5,8$; $\Sigma 356$. From these data an estimation of a total genome size of about $2 \mathrm{Mbp}(1660+356)$ was concluded for Prochlorococcus PCC 9511, in perfect agreement with the renaturation studies. Two other enzymes tested for PFGE (SmaI and NotI) also cut the chromosomal DNA of this strain, but resulted in only a few large bands (data not shown). Given the recognition specificities of the latter enzymes (highly rich in $\mathrm{G}+\mathrm{C}$ ), these results were consistent with the low mean DNA base content of the genome determined by thermal denaturation (see above).

\section{Phylogeny}

Phylogenetic analysis (Fig. 7) of an almost complete 16S rRNA gene sequence of strain PCC 9511 and those of 17 previously determined sequences of cultured and uncultured members of the genus Prochlorococcus revealed that the axenic strain was identical to Prochlorococcus strain CCMP 1378 and exhibited only one base difference with the comparable region (1271 bases common to all Prochlorococcus sequences) of strain CCMP 1426. The two latter strains were both derived from a primary culture, 'MED', isolated from the Mediterranean Sea (Chisholm et al., 1992; Partensky et al., 1993). The same high degree of relatedness ( 1 base difference, but in a different position) was found for Prochlorococcus NATL1, isolated from the North Atlantic (Partensky et al., 1993), whose 16S rRNA sequence was also determined in this study. In contrast, the sequence of strain PCC 9511 differed by 21 bases from that of its supposedly parental culture, Prochlorococcus CCMP $1375^{\mathrm{T}}$, which excluded the possibility that the latter two isolates are co-identic. 


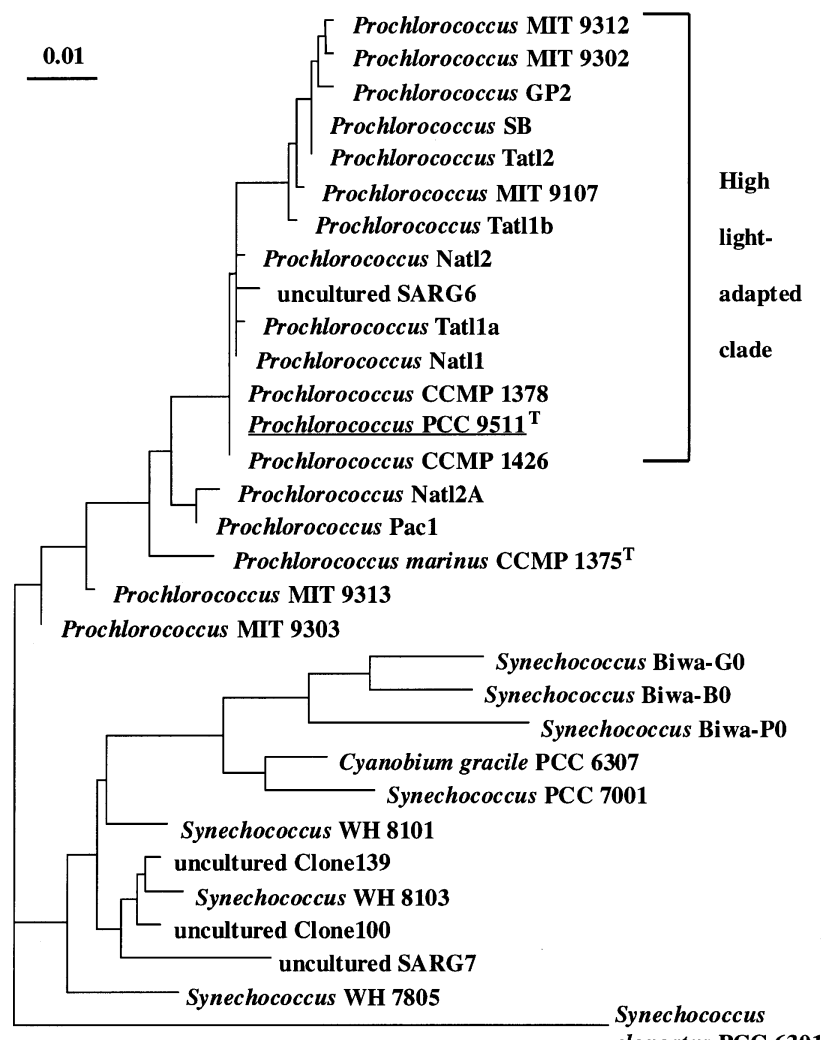

elongatus PCC 6301

Fig. 7. Phylogenetic tree inferred from $16 \mathrm{~S}$ rRNA gene sequences by maximum likelihood (fast DNAml, Olsen et al. 1994) as described in Methods. The axenic strain PCC 9511 is underlined.

\section{DISCUSSION}

The axenic strain Prochlorococcus PCC 9511 will be extremely valuable for research in fundamental microbiology and oceanography. For the first time, physiological, biochemical and genetic studies are possible that can be interpreted without the complexity introduced by potential interactions or interference with commensal contaminants. Although it is unfortunate that growth as single colonies on plates has not yet been achieved, significant progress with respect to the characterization of this axenic strain has been made. It has been shown unambiguously that this isolate is nutritionally relatively versatile, capable of using orthophosphate, polyphosphate and organic phosphates. Since the latter two types of substrates require dephosphorylation prior to crossing the cytoplasmic membrane (Ammerman, 1991), it is clear that strain PCC 9511 must possess one or more ecto-phosphohydrolases. Whether utilization of ATP is mediated by alkaline phosphatase or by a specific 5'-nucleotidase remains to be examined. Both types of ectophosphohydrolases have been found in bacteria (Ammerman, 1991; Martinez \& Azam, 1993; Björkman \& Karl, 1994) and are of great importance for efficient recycling of orthophosphate from organic matter. The presence of such enzyme(s) in Prochloro- coccus is undoubtedly a beneficial adaptation of the organism to its oceanic ecosystem, in which the supply of orthophosphate is thought to be a limiting factor for primary production (Vaulot et al., 1996; Scanlan \& Wilson, 1999). Ammonia and urea are the preferred sources of combined nitrogen for strain PCC 9511. In contrast, nitrate, commonly used by other cyanobacteria (Flores et al., 1983; Flores \& Herrero, 1994) does not support growth. Since molybdenum is a co-factor of nitrate reductase (Guerrero \& Lara, 1987) and uptake of this element may be inhibited at the high concentrations of sulphate typical of seawater (Howarth \& Cole, 1985), lack of growth on nitrate was reconfirmed after increasing the molybdenum concentration in the artificial seawater medium PCR-Tu from $80 \mathrm{nM}$ to 5 and $50 \mu \mathrm{M}$. Inability to utilize nitrate seems to be an ecological contradiction, since field studies demonstrated a positive correlation of Prochlorococcus abundance with nitrate availability (Olson et al., 1990). Thus either the preferential positioning of Prochlorococcus near the nitracline is coincidental or the available nitrate is converted to a utilizable source of nitrogen by other constituents of the autochthonous microbial community. Alternatively, it is possible that Prochlorococcus ecotypes typical of the LL clade, which are adapted to grow at the bottom of the euphotic zone (i.e. near or below the nitracline), may be able to use nitrate more efficiently than members of the HL clade, which generally inhabit the more nitrate-depleted, surface waters (see Partensky et al., 1999). This is suggested by the ability of strain CCMP $1375^{\mathrm{T}}$ to grow on nitrate as the sole source of nitrogen (Moore, 1997). However, since the latter isolate is not axenic, this hypothesis can only be confirmed once pure strains of the LL clade are available.

In the phylogenetic tree inferred from $16 \mathrm{~S}$ rRNA sequences, strain PCC 9511 clusters with members of the HL clade and is identical or closely related to strains CCMP 1378, CCMP 1426, NATL1, TATL2 and NATL2 (Fig. 7). Interestingly, all Prochlorococcus isolates sequenced to date group with marine and freshwater Synechococcus strains, one of which (PCC 6307) was assigned to the 'Cyanobium cluster' (Rippka \& Cohen-Bazire, 1983; Waterbury \& Rippka, 1989). These cyanobacteria have a mean DNA base composition of $59-70 \mathrm{~mol} \% \mathrm{G}+\mathrm{C}$ (Herdman et al., 1979b; Waterbury \& Rippka, 1989) and a genome size of about $4 \mathrm{Mbp}$ (Herdman et al., 1979a). However, strain PCC 9511 has a much lower mean DNA base composition $(32 \mathrm{~mol} \% \mathrm{G}+\mathrm{C}$ ) and its genome is the smallest ( $2 \mathrm{Mbp}$ ) of all photosynthetic prokaryotes. These important genetic differences among members of the same phylogenetic clade raise questions with respect to overall genomic evolutionary events. The low mean DNA base composition of strain PCC 9511 is confirmed by sequence analyses of several genes of cultured and uncultured members of the genus Prochlorococcus: in contrast to marine Synechococcus genotypes of the same 16S rRNA gene clade (i.e. 
strains WH 7803, WH 7805 and WH 8103), the rpoC, $p s b A, p s b B$ or pet $B / D$ genes of most Prochlorococcus isolates studied are characterized by a very low $\mathrm{G}+\mathrm{C}$ content (maximum $38 \mathrm{~mol} \%$ ) in their third codon position (Urbach et al., 1998). An exception to this rule is Prochlorococcus MIT 9303, an isolate at the root of the Prochlorococcus clade (see Fig. 7) that, based on its relatively high $\mathrm{G}+\mathrm{C}$ content $(52-58$ $\mathrm{mol} \%$ ) of the third codon position of the $p s b B$ and pet $B / D$ genes (Urbach et al., 1998), may represent a species of a much higher mean DNA base composition.

In contrast to strain SARG and its clonal derivative CCMP $1375^{\mathrm{T}}$, both of which are members of the LL clade (see Partensky et al., 1999), the axenic strain PCC 9511 is characterized by $\operatorname{chl} b / a_{2}$ ratios lower than $0 \cdot 1$ and a pigment signature typical of the HL clade (Urbach et al., 1998; Partensky et al., 1999). The low content of chl $b$ in strain PCC 9511 is a stable feature, having been observed during four years of subculturing. Furthermore, the 'horseshoe-like' thylakoid arrangement of strain PCC 9511 is more comparable to that described for P. marinus CCMP 1378, a member of the HL clade, than to the concentric thylakoids described for the holotype strain CCMP $1375^{\mathrm{T}}$ (Chisholm et al., 1992; Lichtlé et al., 1995). However, this character may not be clade-specific since strain MIT 9313, a LL representative (Moore et al., 1998), also exhibits in longitudinal sections a 'horseshoe-like' opening of the thylakoids at one pole of the cell (Partensky et al., 1999). As expected for all members of Prochlorococcus, phycobilisomes are lacking in strain PCC 9511 (Fig. 2). In contrast to the holotype CCMP $1375^{\mathrm{T}}$, the genes encoding the novel phycoerythrin (PE-III) (Hess et al., 1996, 1999) seem to be lacking in PCC 9511, and an antiserum to $\alpha$ PE-III did not reveal the corresponding protein subunit (Fig. 5).

In conclusion, the axenic strain PCC 9511 exhibits an ensemble of properties that strongly excludes its coidentity with $P$. marinus strain CCMP $1375^{\mathrm{T}}$, suggesting that the parental culture contained a major and a minor representative of the genus Prochlorococcus, of which only the latter has been rendered axenic. Alternatively, human error of mislabelling cultures, or accidental contamination with a HL representative, cannot entirely be excluded. However, we favour the former explanation, particularly since several other Prochlorococcus cultures have been shown to contain more than one genotype (such as NATL2 versus NATL2A and TATL1A versus TATL1B, Fig. 7; see also Urbach et al., 1998; West \& Scanlan, 1999). Although convincing evidence for the vertical distribution and distinct niche-partitioning of the HL and LL ecotypes, at least in well-stratified water columns, has been obtained for uncultured populations by RNA polymerase gene sequence analyses and 16S rRNAspecific gene probing (Ferris \& Palenik, 1998; West \& Scanlan, 1999), it is equally clear that both HL and LL genotypes co-exist at the same depth (Ferris \& Palenik, 1998; Palenik, 1994; Moore et al., 1998). Consequently, primary non-clonal cultures established from such habitats may change both phenotypic and genotypic signatures over prolonged periods of subculturing as a result of selection by the growth conditions employed. This is exemplified by strain NATL1, which originally exhibited the LL phenotype (chl $b / a_{2}$ ratio in the range of 0.4-0.9) (Partensky et al., 1993; Morel et al., 1993), but changed in the course of maintenance towards a phenotype of a low chl $b / a_{2}$ signature (F. Partensky, unpublished data) and was found to be phylogenetically a member of the HL clade (see Fig. 7). However, the same isolate maintained in another laboratory (S. Chisholm, MIT) as NATL1MIT retained its initial LL pigment signature and yielded a second 16S rRNA gene sequence clustering with LL genotypes (N. West and D. Scanlan, unpublished results).

In order to distinguish strain PCC 9511 and its close relatives of the HL clade from the nomenclatural type, Prochlorococcus marinus strain CCMP $1375^{\mathrm{T}}$ (Chisholm et al., 1992), which is phenotypically and genetically distinct, we propose strain PCC 9511 as the type strain of Prochlorococcus marinus Chisholm et al. 1992 subsp. pastoris subsp. nov. We chose to propose the separation at the subspecies level because no other axenic isolates are presently available for DNA-DNA hybridization studies, necessary for valid separation at the level of species or genus. If the degree of 16S rRNA gene sequence divergence between the low- and highlight clades of Prochlorococcus can be correlated with percentages of DNA-DNA hybridizations and more drastic separations can be justified, the proposed subspecies Prochlorococcus marinus subsp. pastoris could be elevated to a higher taxonomic rank. The epithet of the new subspecies, pastoris, was chosen in honour of Louis Pasteur, since his famous citation (Vallery-Radot, 1939) 'dans le champ d'observation, le hasard ne favourise que les esprits préparés' (in the field of observations, chance only favours the prepared mind) is highly appropriate in the context of the rather fortuitous purification of strain PCC 9511.

\section{Description of Prochlorococcus marinus subsp. pastoris subsp. nov.}

Prochlorococcus marinus Chisholm et al. 1992, 299. The diagnoses of the latter genus and type species correspond to those formulated by Chisholm et al. (1992). They are here extended, in order to distinguish between two of the different pheno- and genotypes within the type species, leading to the proposal of the following subspecies.

Prochlorococcus marinus Chisholm et al. 1992 subsp. marinus subsp. nov. Chisholm et al. 1992. The type strain of this subspecies is the non-axenic holotype of the genus, strain CCMP $1375^{\mathrm{T}}$. The cells are spherical to slightly elongated $(0.6-0.8 \mu \mathrm{m}$ in diameter; pre-divisional cells are $1.2-1.6 \mu \mathrm{m}$ in length); thylakoids are arranged concentrically at the periphery of the cells; the genes encoding the $\alpha$ and $\beta$ subunits of phycoerythrin (PEIII) are present and translated; chlorophylls $a_{2}, b_{1}, b_{2}$ 
and $\mathrm{Mg}$, 3-8 divinyl phaeoporphyrin $\mathrm{a}_{5}$ are synthesized; the ratios of chlorophyll $b\left(b_{1}\right.$ and $\left.b_{2}\right)$ over chl $a_{2}$ are in the range of $0 \cdot 4-2 \cdot 4$. Zeaxanthin and $\alpha$-carotene are the major carotenoids. The mean DNA base composition and genome size are unknown.

Prochlorococcus marinus Chisholm et al. 1992 subsp. pastoris subsp. nov. The type strain of the new subspecies, pastoris (pa.sto'ris. Latinized form of Pasteur), is the axenic isolate PCC 9511 (= ATCC 700925). The cells of this strain are $0.5-0.6 \mu \mathrm{m}$ in width and $0.7-0.8 \mu \mathrm{m}$ in length; thylakoids have a 'horseshoe-like' opening at one pole of the cells; phycoerythrin is not produced and the genes encoding the $\alpha$ and $\beta$ subunits of phycoerythrin (PE-III) have not been revealed in the genome; chlorophylls $a_{2}, b_{2}$ and $\mathrm{Mg}, 3-8$ divinyl phaeoporphyrin $\mathrm{a}_{5}$ are synthesized, but chl $b_{1}$ is lacking; the ratios of chlorophyll $b_{2} / a_{2}$ are less than $0 \cdot 1$. As observed for all other non-axenic members of this genus, zeaxanthin and $\alpha$-carotene are the major carotenoids. Strain PCC 9511 uses ammonia and urea as the preferred sources of nitrogen, but is incapable of using nitrate. Utilizable sources of phosphate are: Na$\mathrm{PO}_{4}(\mathrm{pH} 7 \cdot 5), \mathrm{Na}_{2}$ - $\beta$-glycerophosphate, $\mathrm{Na}_{4}$-pyrophosphate, glucose 6-phosphate and ATP; the mean DNA base composition is $32 \mathrm{~mol} \% \mathrm{G}+\mathrm{C}$; genome size is $2 \mathrm{Mbp}$. Based on morphology, pigment content and $16 \mathrm{~S}$ rRNA sequence analyses, the type strain of this new subspecies is identical to the impure strain CCMP 1378 (MED4), isolated from the Mediterranean Sea. Both are highly related to four other non-axenic isolates, CCMP 1426, NATL1, TATL2 and NATL2, which most likely are also assignable to the subspecies pastoris. The former two differ from PCC 9511 by one base at two different positions; the latter exhibit two different base changes in the respective $16 \mathrm{~S}$ rRNA sequences that cover a total of 1271 comparable bases. In contrast, the type strain CCMP $1375^{\mathrm{T}}$ of the genus and proposed as Prochlorococcus marinus Chisholm et al. 1992 subsp. marinus subsp. nov., differs in the $16 \mathrm{~S}$ rRNA gene sequence by 20-21 bases from all six members of the subspecies pastoris.

\section{ACKNOWLEDGEMENTS}

The authors acknowledge the participation of Julie Newman (Warwick, UK) in the determination of the 16S rRNA sequences of strains NATL1 and CCMP 1426. Bernard Rousseau (ENS, Paris) and Dr Gerhard Sandman (University of Frankfurt, Germany) are acknowledged for having performed pigment analyses. R. R. is grateful for stimulating discussions with Dr José M. Garcia-Fernandez (Cordoba, Spain) and wishes to thank Thierry Laurent, in charge of the fastidious harvesting procedure of cells for the DNA preparation, for his competent help. Jacqueline Lefebvre kindly helped with the bibliography. Drs Nicole Tandeau de Marsac (Institut Pasteur, Paris) and Daniel Vaulot (Station Biologique, Roscoff, France) did not wish to co-author this work in order to reduce the number of authors. Their encouragement and helpful discussions are highly appreciated. The work was supported by the Institut Pasteur, the Centre National de la Recherche Scientifique (CNRS, URA
1129), and in part by the contract BIO4-CT96-0256 (BASIC) of the European programme BIOTECH (Life Sciences and Technologies, Biotechnology Programme, 1994-1998). Additional funding was by the EC programme MAST 3-CT97-0128 (Promolec) and by the Deutsche Forschungsgemeinschaft (to W.R.H.). D.J.S. is a Royal Society University Research Fellow.

\section{REFERENCES}

Alberte, R. S., Wood, A. M., Kursar, T. A. \& Guillard, R. R. L. (1984). Novel phycoerythrins in marine Synechococcus spp. Characterization and evolutionary and ecological implications, Plant Physiol 75, 732-739.

Ammerman, J. W. (1991). Role of ecto-phosphohydrolases in phosphorus regeneration in estuarine and coastal ecosystems. In Microbial Enzymes in Aquatic Environments, pp. 165-186. Edited by R. J. Chrost. New York: Springer.

Björkman, K. \& Karl, D. M. (1994). Bioavailability of inorganic and organic phosphorus compounds to natural assemblages of microorganisms in Hawaiian coastal waters, Mar Ecol Prog Ser 111, 265-273.

Bogorad, L. (1975). Phycobiliproteins and complementary chromatic adaptation, Annu Rev Plant Physiol 26, 369-401.

Bruland, K. W. (1983). Trace elements in seawater. In Chemical Oceanography, vol. 6, pp. 157-220. Edited by J. P. Riley \& R. Chester. London: Academic Press.

Bryant, D. A. (1982). Phycoerythrocyanin and phycoerythrin: properties and occurrence in cyanobacteria, J Gen Microbiol 128, 835-844.

Burger-Wiersma, T., Veenhuis, M., Korthals, H. J., Van de Wiel, C. C. M. \& Mur, L. R. (1986). A new prokaryote containing chlorophylls $a$ and $b$, Nature 320, 262-264.

Cai, Y. \& Wolk, C. P. (1990). Use of a conditionally lethal gene in Anabaena sp. strain PCC 7120 to select for double recombinants and to entrap insertion sequences, J Bacteriol 172, 3138-3145.

Castenholz, R. W. \& Waterbury, J. B. (1989). Oxygenic photosynthetic bacteria. Group I. Cyanobacteria. Preface. In Bergey's Manual of Systematic Bacteriology, pp. 1710-1727. Edited by J. T. Staley, M. P. Bryant, N. Pfenning \& J. G. Holt. Baltimore: Williams \& Wilkins.

Chisholm, S. W., Olson, R. J., Zettler, E. R., Goericke, R., Waterbury, J. B. \& Welschmeyer, N. A. (1988). A novel free-living prochlorophyte abundant in the oceanic euphotic zone, Nature 334, 340-343.

Chisholm, S. W., Frankel, S. L., Goericke, R., Olson, R. J., Palenik, B., Waterbury, J. B., West-Johnsrud, L. \& Zettler, E. R. (1992). Prochlorococcus marinus nov. gen. nov. sp.: an oxyphototrophic marine prokaryote containing divinyl chlorophyll $a$ and $b$, Arch Microbiol 157, 297-300.

Churin, Y. N., Shalak, I. N., Börner, T. \& Shestakov, S. V. (1995). Physical and genetic map of the chromosome of the unicellular cyanobacterium Synechocystis sp. strain PCC 6803, J Bacteriol 177, 3337-3343.

Felsenstein, J. (1993). PHYLIP (Phylogeny Inference Package) version 3.5c. Seattle: University of Washington.

Ferris, M. J. \& Palenik, B. (1998). Niche adaptation in ocean cyanobacteria, Nature 396, 226-228.

Flores, E. \& Herrero, A. (1994). Assimilatory nitrogen metabolism and its regulation. In The Molecular Biology of Cyanobacteria, pp. 487-517. Edited by D. A. Bryant. Dordrecht: Kluwer Academic Publishers. 
Flores, E., Ramos, J. L., Herrero, A. \& Guerrero, M. G. (1983). Nitrate assimilation by cyanobacteria. In Photosynthetic Prokaryotes: Cell Differentiation and Function, pp. 363-387. Edited by G. C. Papageorgiou \& L. Packer. New York: Elsevier Biomedical.

Garczarek, L., van der Staay, G. W. M., Thomas, J. C. \& Partensky, F. (1998). Isolation and characterization of photosystem I from two strains of the marine oxychlorobacterium Prochlorococcus, Photosynth Res 56, 131-141.

Glazer, A. N. (1987). Phycobilisomes: assembly and attachment. In The Cyanobacteria, pp. 69-94. Edited by P. Fay \& C. Van Baalen. Amsterdam: Elsevier.

Glazer, A. N. (1989). Light guides. Directional energy transfer in a photosynthetic antenna, $J$ Biol Chem 264, 1-4.

Goericke, R. \& Repeta, D. J. (1992). The pigments of Prochlorococcus marinus: the presence of divinyl chlorophyll $a$ and $b$ in a marine procaryote, Limnol Oceanogr 37, 425-433.

Goericke, R. \& Repeta, D. J. (1993). Chlorophylls $a$ and $b$ and divinyl chlorophylls $a$ and $b$ in the open subtropical North Atlantic Ocean, Mar Ecol Prog Ser 101, 307-313.

Grossman, A. R., Schaefer, M. R., Chiang, G. G. \& Collier, J. L. (1994). The responses of cyanobacteria to environmental conditions: light and nutrients. In The Molecular Biology of Cyanobacteria, pp. 641-675. Edited by D. A. Bryant. Dordrecht: Kluwer Academic Publishers.

Guerrero, M. G. \& Lara, C. (1987). Assimilation of inorganic nitrogen. In The Cyanobacteria, pp. 163-186. Edited by P. Fay \& C. Van Baalen. Oxford: Elsevier.

Herdman, M., Janvier, M., Rippka, R. \& Stanier, R. Y. (1979a). Genome size of cyanobacteria, J Gen Microbiol 111, 73-85.

Herdman, M., Janvier, M., Waterbury, J. B., Rippka, R., Stanier, R. Y. \& Mandel, M. (1979b). Deoxyribonucleic acid base composition of cyanobacteria, J Gen Microbiol 111, 63-71.

Hess, W. R., Weihe, A., Loiseaux-de Goër, S., Partensky, F. \& Vaulot, D. (1995). Characterization of the single $p s b A$ gene of Prochlorococcus marinus CCMP 1375 (Prochlorophyta), Plant Mol Biol 27, 1189-1196.

Hess, W. R., Partensky, F., van der Staay, G. W. M., GarciaFernandez, J. M., Börner, T. \& Vaulot, D. (1996). Coexistence of phycoerythrin and a chlorophyll $a / b$ antenna in a marine prokaryote, Proc Natl Acad Sci USA 93, 11126-11130.

Hess, W. R., Steglich, C., Lichtlé, C. \& Partensky, F. (1999). Phycoerythrins of the oxyphotobacterium Prochlorococcus marinus are associated to the thylakoid membranes and are encoded by a single large gene cluster, Plant Mol Biol 40, 507-521.

Honda, D., Yokota, A. \& Sugiyama, J. (1999). Detection of seven major evolutionary lineages in cyanobacteria based on the $16 \mathrm{~S}$ rRNA gene sequence analysis with new sequences of five marine Synechococcus strains, J Mol Evol 48, 723-739.

Howarth, R. \& Cole, J. J. (1985). Molybdenum availability, nitrogen limitation, and phytoplankton growth in natural waters, Science 229, 653-655.

Iteman, I., Rippka, R., Tandeau de Marsac, N. \& Herdman, M. (1999). Use of molecular tools for the study of genetic relationships of heterocystous cyanobacteria. In Marine Cyanobacteria, Bulletin de l'Institut Océanographique, Monaco, special issue 19, pp. 13-20. Edited by L. Charpy \& A. W. D. Larkum. Monaco: Institute Océanographique.

Kaplan, A., Schwarz, R., Lieman-Hurwitz, J., Ronen-Tarazi, M. \& Reinhold, L. (1994). Physiological and molecular studies on the response of cyanobacteria to changes in the ambient inorganic carbon concentration. In The Molecular Biology of Cyanobacteria, pp. 469-485. Edited by D. A. Bryant. Dordrecht: Kluwer Academic Publishers.

Kishino, H., Miyata, T. \& Hasegawa, M. (1990). Maximum likelihood inference of protein phylogeny and the origin of chloroplasts, J Mol Evol 31, 151-160.

Kraay, G. W., Zapata, M. \& Veldhuis, M. J. (1992). Separation of chlorophylls $c_{1}, c_{2}$, and $c_{3}$ of marine phytoplankton by reversedphase-C18-high-performance liquid chromatography, Proc Natl Acad Sci USA 28, 708-712.

Lewin, R. A. (1977). Prochloron, type genus of the Prochlorophyta, Phycologia 16, 217.

Lewin, R. A. (1989). Group II. Order Prochlorales. In Bergey's Manual of Systematic Bacteriology, pp. 1799-1805. Edited by J. T. Staley, M. P. Bryant, N. Pfenning \& J. G. Holt. Baltimore: Williams \& Wilkins.

Li, W. K. W. \& Wood, A. M. (1988). Vertical distribution of North Atlantic ultraphytoplankton: analysis by flow cytometry and epifluorescence microscopy, Deep Sea Res 35, 1615-1638.

Lichtlé, C., Thomas, J. C., Spilar, A. \& Partensky, F. (1995). Immunological and ultrastructural characterization of the photosynthetic complexes of the prochlorophyte Prochlorococcus (oxychlorobacteria), J Phycol 31, 934-941.

Liotenberg, S., Campbell, D., Rippka, R., Houmard, J. \& Tandeau de Marsac, N. (1996). Effect of the nitrogen source on phycobiliprotein synthesis and cell reserves in a chromatically adapting filamentous cyanobacterium, Microbiology 142, 611-622.

Lockhart, P. J., Beanland, T. J., Howe, C. J. \& Larkum, A. W. D. (1992). Sequence of Prochloron didemni atpBE and the inference of chloroplast origins, Proc Natl Acad Sci USA 89, 2742-2746.

Lokstein, H., Steglich, C. \& Hess, W. R. (1999). Light-harvesting antenna function of phycoerythrin in Prochlorococcus marinus, Biochim Biophys Acta 1410, 97-98.

McLachlan, J. (1973). Growth media-marine. In Handbook of Phycological Methods: Culture Methods and Growth Measurements, pp. 25-51. Edited by J. R. Stein. Cambridge: University Press.

Martinez, J. \& Azam, F. (1993). Periplasmic aminopeptidase and alkaline phosphatase activities in a marine bacterium: implications for substrate processing in the sea, Mar Ecol Prog Ser 92, 89-97.

Moore, L. R. (1997). Physiological ecology of Prochlorococcus: a comparison of isolates from diverse oceanographic regimes. $\mathrm{PhD}$ thesis, Massachusetts Institute of Technology.

Moore, L. R., Goericke, R. \& Chisholm, S. W. (1995). Comparative physiology of Synechococcus and Prochlorococcus: influence of light and temperature on growth, pigments, fluorescence and absorptive properties, Mar Ecol Prog Ser 116, 259-275.

Moore, L. R., Rocap, G. \& Chisholm, S. W. (1998). Physiology and molecular phylogeny of coexisting Prochlorococcus ecotypes, Nature 393, 464-467.

Morel, A., Ahn, Y.-H., Partensky, F., Vaulot, D. \& Claustre, H. (1993). Prochlorococcus and Synechococcus: a comparative study of their optical properties in relation to their size and pigmentation, J Mar Res 51, 617-649.

Olsen, G. J., Matsuda, H., Hagstrom, R. \& Overbeek, R. (1994). fastDNAml: a tool for construction of phylogenetic trees of DNA sequences using maximum likelihood, CABIOS 10, 41-48.

Olson, R. J., Chisholm, S. W., Zettler, E. R., Altabet, M. A. \& Dusenberry, J. A. (1990). Spatial and temporal distributions of 
prochlorophyte picoplankton in the North Atlantic Ocean, Deep Sea Res 37, 1033-1051.

Ong, L. J. \& Glazer, A. N. (1991). Phycoerythrins of marine unicellular cyanobacteria. I. Bilin types and locations and energy transfer pathways in Synechococcus spp. phycoerythrins, J Biol Chem 266, 9515-9527.

Palenik, B. (1994). Cyanobacterial community structure as seen from RNA polymerase gene sequence analysis, Appl Environ Microbiol 60, 3212-3219.

Palenik, B. \& Haselkorn, R. (1992). Multiple evolutionary origins of prochlorophytes, the chlorophyll $b$-containing prokaryotes, Nature 355, 265-267.

Partensky, F., Hoepffner, N., Li, W. K. W., Ulloa, O. \& Vaulot, D. (1993). Photoacclimation of Prochlorococcus sp. (Prochlorophyta) strains isolated from the North Atlantic and the Mediterranean Sea, Plant Physiol 101, 285-296.

Partensky, F., LaRoche, J., Wyman, K. \& Falkowski, P. G. (1997). The divinyl-chlorophyll $a / b$-protein complexes of two strains of the oxyphototrophic marine prokaryote Prochlorococcus-characterization and response to changes in growth irradiance, Photosynth Res 51, 209-222.

Partensky, F., Hess, W. R. \& Vaulot, D. (1999). Prochlorococcus, a key marine photosynthetic prokaryote, Microbiol Mol Biol Rev 63, 106-127.

Pinevich, A. V., Averina, S. G. \& Velichko, N. V. (1997). Another view on the role of photosynthetic pigments in taxonomy of oxygenic-phototrophic bacteria: proposed rejection of the order Prochlorales Florenzano, Balloni, and Materassi 1986 (emend. Burger-Wiersma, Stal, and Mur 1989), the family Prochloraceae Florenzano, Balloni, and Materassi 1986, and the family Prochlorotrichaceae Burger-Wiersma, Stal, and Mur 1989, Int J Syst Bacteriol 47, 1264-1267.

Rippka, R. (1988). Isolation and purification of cyanobacteria, Methods Enzymol 167, 3-27.

Rippka, R. \& Cohen-Bazire, G. (1983). The cyanobacteriales: a legitimate order based on the type strain Cyanobacterium stanieri? Ann Microbiol (Inst Pasteur) 134B, 21-36.

Rippka, R., Deruelles, J., Waterbury, J. B., Herdman, M. \& Stanier, R. Y. (1979). Generic assignments, strain histories and properties of pure cultures of cyanobacteria, J Gen Microbiol 111, 1-61.

Ruimy, R., Breitmeyer, V., Elbaze, P., Lafay, B., Boussemart, O., Gauthier, M. \& Christen, E. (1994). Phylogenetic analysis and assessment of the genera Vibrio, Photobacterium, Aeromonas, and Plesiomonas deduced from small-subunit rRNA sequences, Int J Syst Bacteriol 44, 416-426.

Sambrook, J., Fritsch, E. F. \& Maniatis, T. (1989). Molecular Cloning: a Laboratory Manual, 2nd edn. Cold Spring Harbor, NY: Cold Spring Harbor Laboratory.

Scanlan, D. J. \& Wilson, W. H. (1999). Application of molecular techniques to addressing the role of $\mathrm{P}$ as a key effector in marine ecosystems, Hydrobiologia 401, 149-175.

Scanlan, D. J., Hess, W. R., Partensky, F., Newman, J. \& Vaulot, D. (1996). High degree of genetic variation in Prochlorococcus (Prochlorophyta) revealed by RFLP analysis, Eur J Phycol 31, $1-9$.

Schyns, G., Rippka, R., Namane, A., Campbell, D., Herdman, M. \& Houmard, J. (1997). Prochlorothrix hollandica PCC 9006: genomic properties of an axenic representative of the chloro- phyll $a / b$-containing oxyphotobacteria, Res Microbiol 148, 345-354.

Sidler, W. A. (1994). Phycobilisome and phycobiliprotein structures. In The Molecular Biology of Cyanobacteria, pp. 139-216. Edited by D. A. Bryant. Dordrecht: Kluwer Academic Publishers.

Skulberg, O. M. (1990). Culture Collection of Algae, Norwegian Institute for Water Research, Catalogue of strains 1990. Oslo: Norwegian Institute for Water Research (NIVA).

Swanson, R. V., Ong, L. J., Wilbanks, S. M. \& Glazer, A. N. (1991). Phycoerythrins of marine unicellular cyanobacteria. II. Characterization of phycobiliproteins with unusually high phycourobiliprotein content, J Biol Chem 266, 9528-9534.

Tandeau de Marsac, N. \& Houmard, J. (1988). Complementary chromatic adaptation: physiological conditions and action spectra, Methods Enzymol 167, 318-328.

Tandeau de Marsac, N. \& Houmard, J. (1993). Adaptation of cyanobacteria to environmental stimuli: new steps towards molecular mechanisms, FEMS Microbiol Rev 104, 119-190.

Turner, S., Burger-Wiersma, T., Giovannoni, S. J., Mur, L. R. \& Pace, N. R. (1989). The relationship of a prochlorophyte Prochlorothrix hollandica to green chloroplasts, Nature 337, 380-382.

Urbach, E., Robertson, D. L. \& Chisholm, S. W. (1992). Multiple evolutionary origins of prochlorophytes within the cyanobacterial radiation, Nature 355, 267-270.

Urbach, E., Scanlan, D. J., Distel, D. L., Waterbury, J. B. \& Chisholm, S. W. (1998). Rapid diversification of marine picophytoplankton with dissimilar light-harvesting structures inferred from sequences of Prochlorococcus and Synechococcus (cyanobacteria), J Mol Evol 46, 188-201.

Vallery-Radot, R. (1939). Discours [prononcé à Douai, le 7 Décembre 1854, à l'occasion de l'installation solennelle de la faculté des lettres de Douai et de la faculté des sciences de Lille]. In Oeuvres de Pasteur. Tome VII. Mélanges Scientifiques et Littéraires. Paris: Masson.

Vaulot, D., LeBot, N., Marie, D. \& Fukai, E. (1996). Effect of phosphorus on the Synechococcus cell cycle in surface Mediterranean waters during summer, Appl Environ Microbiol 62, 2527-2533.

Waterbury, J. B. \& Rippka, R. (1989). Subsection I. Order Chroococcales Wettstein 1924, emend. Rippka et al. 1979. In Bergey's Manual of Systematic Bacteriology, pp. 1728-1746. Edited by J. T. Staley, M. P. Bryant, N. Pfenning \& J. G. Holt. Baltimore: Williams \& Wilkins.

Waterbury, J. \& Stanier, R. Y. (1977). Two unicellular cyanobacteria which reproduce by budding, Arch Microbiol 115, 249-257.

Waterbury, J. B. \& Willey, J. M. (1988). Isolation and growth of marine planktonic cyanobacteria, Methods Enzymol 167, 100-105.

West, N. J. \& Scanlan, D. J. (1999). Niche-partitioning of Prochlorococcus populations in a stratified water column in the eastern North Atlantic ocean, Appl Environ Microbiol 65, 2585-2591.

Willmotte, A., van der Auwera, G. \& de Wachter, R. (1993). Structure of the $16 \mathrm{~S}$ ribosomal RNA of the thermophilic cyanobacterium Chlorogloeopsis HTF ('Mastigocladus laminosus $\mathrm{HTF}$ ') strain PCC 7518, and phylogenetic analysis, FEBS Lett 317, 96-100. 